Archives of Agriculture and Environmental Science

\title{
Adding benefits to phytoremediation of sugar mill effluent by growing water hyacinth (Eichhornia crassipes): Evaluation of biomass for biogas production
}

\section{Vinod Kumar, Jogendra Singh* (D) and Pankaj Kumar}

Agro-ecology and Pollution Research Laboratory, Department of Zoology and Environmental Science, Gurukula Kangri Vishwavidyalaya Haridwar-249404 (Uttarakhand), INDIA

"Corresponding author's E-mail: jogendrasinghpatil@gmail.com

\section{ARTICLE HISTORY}

Received: 25 June 2018

Revised received: 02 August 2018

Accepted: 15 August 2018

\section{Keywords}

Biogas production

Modified Gompertz kinetic model

Phytoremediation

Plant growth kinetics

Sugar mill effluent

Water hyacinth

\begin{abstract}
In this experiment, we assessed the phytoremediation potential of water hyacinth (Eichhornia crassipes) for pollutants removal from sugar mill effluent amended at different concentrations and further biogas production from its grown biomass co-digested with cow dung in a laboratory scale anaerobic digester. The results showed that the maximum values of kinetic growth rate $\left(2.56 \mathrm{gg}^{-1} \mathrm{~d}^{-1}\right)$, total chlorophyll content $(4.10 \pm 0.10 \mathrm{mg} / \mathrm{gfwt}$.) and fresh plant biomass $(393.87 \pm 4.67 \mathrm{~g} / \mathrm{Kg})$ of E. crassipes were achieved in $75 \%$ concentration of sugar mill effluent after 60 days of phytoremediation experiments. Also, the enrichment factor $\left(E_{f}\right)$ and bioaccumulation factor $\left(B_{f}\right)$ of heavy metals were greater than or equal to 1 in the roots and leaves of $E$. crassipes which indicated efficient elimination of these metals from the sugar mill effluent. Significant values of cumulative biogas production $(5195 \mathrm{ml})$ and predicted by modified Gompertz kinetic model $(5238.71 \mathrm{ml})$ were found after 15 days of anaerobic digestion at $40^{\circ} \mathrm{C}$ with maximum reduction of COD (83.11\%) of the substrate slurry. The plot of $\log (\mathrm{COD}) \mathrm{vs}$. $t$ (HRT) suggested good fitness of first order kinetic equation $\left(R^{2}=0.9746\right)$ for reduction of co-substrate COD. The different kinetic parameters of COD reduction for biogas production viz., a $x c$ and $k$ were noted as $6096.12,7.73$ and 0.26 , with $\mathrm{R}^{2}$ value of 0.99 , respectively. The findings of this study concluded that E. crassipes can be used for the phytoremediation of heavy metals and other pollutants most efficiently in $75 \%$ concentration of the sugar mill effluent. Additionally, the biomass of E. crassipes grown during phytoremediation can be used for enhanced biogas production.
\end{abstract}

(C)2018 Agriculture and Environmental Science Academy

Citation of this article: Kumar, V., Singh, J. and Kumar, P. (2018). Adding benefits to phytoremediation of sugar mill effluent by growing water hyacinth (Eichhornia crassipes): Evaluation of biomass for biogas production. Archives of Agriculture and Environmental Science, 3(3): 275-288, https://dx.doi.org/10.26832/24566632.2018.0303011

\section{INTRODUCTION}

Globally, the species of the aquatic macrophytes are frequently being tested for their phytoremediation potential using diverse nature of industrial effluents with varied characteristics (Kumar and Chopra, 2016). The rapid and continuous growth of industrial sector has raised the economy of the nation, but, on the other hand it has also degraded all part of the environment as air, water and soil (Mishra and Maiti, 2016). The sugar industry effluent has various pollutants which cause water pollution in the aquatic as well as soil ecosystems when released without proper treatments. The effluent produced during the manufac- ture of sugar contains a greater amount of pollution load mainly the suspended solids, organic matters, press-mud, bagasse and higher microbial load (Daulta et al., 2014). Farmers have been frequently using these effluents for the irrigation purpose in the field crops due to its higher nutrient values while continuously irrigation gradually affect the soil health and accumulate numerous toxicants. In the aquatic environment, addition of different pollutants such as chloride, sulphate, phosphate, magnesium and nitrate of the sugar mill effluent are responsible for eutrophication in the water bodies. Therefore, disposal of the sugar mill effluent in the aquatic resources severely affect the survival of living organisms (Ayyasamy et al., 2008). The major 
shortcomings of the electric-current, physical, chemical, filtration and adsorbent based technologies for the large scale treatment of the wastewater are the higher input cost and complex manufacture, operation, and maintenance practices makes them limited (Annadurai et al., 2002; Mishra and Maiti, 2016).

The phytoremediation is an alternate biological method to remediate the excess nutrients and heavy metal contaminants from the wastewaters. Phytoremediation technology is continuously receiving attention as an innovative, profitable substitute for the treatment of industrial effluents (Kumar et al., 2016). The efficiently capable aquatic macrophytes are widely used to eliminate a wide range of micro and macro elements, metals by means of surface adsorption and/or absorption (Fernando et al., 2008). These plants absorb the nutrients from the wastewaters and grow more rapidly which makes the process more sustainable to reduce the load efficiently. Hence, such plants are playing prominent role in effective management of industrial wastewaters by recycling the contaminants and help in making aquatic ecosystem cleaner (Kumar et al., 2017a).

Water hyacinth (E. crassipes) is magnificent aquatic macrophytes as it has high potential to decontaminate the submerged aquatic ecosystems. The dense hairy roots of $E$. crassipes play major role in effectively absorbing a wide range of nutrients and heavy metals from their supplemented medium and further translocate them in different aerial parts (stem and leaves) by means of biological filtration system (Dhote and Dixit, 2009). The water hyacinth plants are also biochemically rich in hemicellulosic content (22-33.97\% dry weight) and carbon/nitrogen ratio (20-35) which makes it good substratum for production of biofuels (Jayaweera et al., 2007).

Utilization of the plant-based biomass for production of biogas has become an innovative and emerging approach for fulfilling the global energy demands. The biomass of aquatic macrophytes grown during the phytoremediation process has good potential for generation of biogas and, furthermore, the left over digested substrate can be used as biofertilizer (Kumar et al., 2017a). Using plant biomass with diverse types of co-substrates increases the biofuel production efficiency (Mishra and Maiti, 2016; Kumar et al., 2017a, b).

Thus, no comprehensive report is available on the phytoremediation of the sugar mill effluent by water hyacinth and the use of grown biomass of for biogas production. Keeping in view, the present investigation was planned to assess the potential of E. crassipes for pollutant elimination from sugar mill effluent and further biogas production using its grown biomass.

\section{MATERIALS AND METHODS}

Experimental setup, collection and characterization of sugar mill effluent

The phytoremediation experiments were conducted in the Multipurpose Experimental Area (MEA) of the Department of Zoology and Environmental Science, Gurukula Kangri Vishwavidyalaya, Haridwar (Uttarakhand), India (29 $55^{\prime} 13^{\prime \prime} \mathrm{N}$ and
78 $70^{\prime} 23^{\prime \prime} E$. For this, sugar mill effluent samples were taken from the effluent disposal site of Uttam Sugar Mills Ltd. in Libberheri village of Roorkee, Haridwar (Uttarakhand) $\left(29^{\circ}\right.$ $44^{\prime} 38^{\prime \prime} \mathrm{N}$ and $\left.77^{\circ} 51^{\prime} 14 " \mathrm{E}\right)$ into 25 liter capacity plastic canes. The samples were brought to the laboratory and analyzed for various physico-chemical, microbiological and heavy metals. The phytoremediation experiments were carried out in the glass aquariums (25 liters capacity) in different concentrations (25\%, $50 \%, 75 \%$ and $100 \%)$ of the sugar mill effluent. The different concentrations i.e., $25 \%$ ( 5 liter sugar mill effluent +15 liter bore well water), $50 \%$ (10 liter sugar mill effluent +10 liter bore well water), $75 \%$ (15 liter sugar mill effluent +5 liter bore well water) and $100 \%$ (absolute effluent) of the sugar mill effluent were achieved by diluting the sugar mill effluent with bore well water. A total twenty liter of treatment sample was taken in the glass aquarium and three pre-weighed healthy plants of E. crassipes were transplanted in the effluent. The experiment was run for a period of 60 days and replicated three times and arranged in block design. A control investigation was also undertaken to grow E. crassipes in bore well water. The experiments were performed with retention time of $24 \mathrm{hrs}$. and lasted for 60 days. The various physico-chemical, microbiological and heavy metals parameter of sugar mill effluent viz., $\mathrm{pH}$, electrical conductivity (EC), total dissolved solid (TDS), biological oxygen demand (BOD), chemical oxygen demand (COD), total Kjeldhal nitrogen $(\mathrm{TKN})$, phosphorus $(\mathrm{P})$, calcium (Ca), magnesium $(\mathrm{Mg})$, sodium (Na) and potassium (K); standard plate count (SPC), most probable number (MPN); cadium (Cd), copper (Cu), chromium (Cr), iron (Fe), lead $(\mathrm{Pb})$, manganese $(\mathrm{Mn})$ and zinc $(\mathrm{Zn})$ were analyzed by following the standard methods prescribed by AOAC (2005) and APHA (2012).

Description and collection of the test plant species (E. crassipes) E. crassipes is a free floating, invasive weed and perennial aquatic macrophytes which belongs to the family Pontederiaceae. It is dominantly found in the local aquatic bodies of Northern India and able to grown in a wide range of highly enriched water bodies like ponds, lakes and wetlands. Having good ability to absorb or accumulate a wide variety of contaminants in their vegetative parts also makes this species more suitable for phytoremediation. Healthy plants of E. crassipes were collected from the pond situated at Jamalpur Kalan (29.91'20' $\mathrm{N}$ and $78^{\circ}$ 13'08'E) near Gurukula Kangri Vishwavidyalaya Haridwar (Uttarakhand), India. The plants of E. crassipes were familiarized in the MEA for one week by placing them in a common macrophytes culture pond to let adapt in the new environment. Finally, the plants of the equal size and weight were transplanted in the glass aquariums for the phytoremediation process.

\section{Calculation of percent pollutants removal efficiency $\left(R_{e}\right)$}

The percent removal efficiency of pollutants from sugar mill effluent by E. crassipes was calculated by using the Equation 1 (Hurst, 1997; Kumar et al., 2017a, b):

$$
\text { Removal Efficiency }\left(R_{e} \%\right)=\frac{c_{\mathrm{i}}-C_{f}}{c_{\mathrm{i}}} \times 100
$$


Where, $C_{i}$ is the initial concentration of the pollutant in the medium and $C_{f}$ is the final concentration of the pollutant in the medium.

\section{Heavy metals analysis}

Both the sugar mill effluent and plants were analyzed for heavy metal ( $\mathrm{Cd}, \mathrm{Cu}, \mathrm{Cr}, \mathrm{Fe}, \mathrm{Pb}, \mathrm{Mn}$ and $\mathrm{Zn}$ ) during the phytoremediation experiments. For this, $10 \mathrm{~mL}$ of sugar mill effluent and $1.0 \mathrm{~g}$ of air dried root and leaves samples of $E$. crassipes were taken out in the digestion tubes separately and 3 $\mathrm{mL}$ of conc. $\mathrm{HNO}_{3}$ was added. Each digestion tube was digested in an electrical heating block for a period of $1 \mathrm{hr}$. at $150^{\circ} \mathrm{C}$. The mixtures were cooled and filtered using Whatman No. 42 filter paper. The final volume was made to $50 \mathrm{~mL}$ by addition of $1 \%$ $\mathrm{HNO}_{3}$ and further used for heavy metals analysis using an atomic absorption spectrophotometer instrument(PerkinElmer, Analyst 800 AAS, GenTeh Scientific Inc., Arcade, NY) following the standard methods (AOAC, 2005; Chaturvedi and Sankar, 2006; APHA, 2012).

\section{Calculation of plant growth parameters}

Fresh weight and total chlorophyll content of E. crassipes plants were at intervals of $0,15,30,45$ and 60 days in each treatment of the sugar mill effluent. Fresh weight of E. crassipes was determined by using a digital balance. The total chlorophyll content of E. crassipes was analyzed using acetone extraction method and the absorbance were recorded in a spectrophotometer (Agilent 60 Cary, UV-Vis Spectroscopy); (Aron, 1949).

\section{Calculation of kinetic growth rate}

The kinetic growth rate of E. crassipes plants was calculated by evaluating the initial weight with the final weight. The kinetic growth rate was calculated by using the Equation 2 (Hunt, 1978):

$$
\text { Kinetic growth rate }=\frac{\operatorname{In} W_{a}-\operatorname{In} W_{z}}{\mathrm{t} 2-\mathrm{t} 1}
$$

Where, $\ln _{a}$ and $\ln W_{z}$ are the logarithms of initial fresh biomass and final fresh biomass at harvest, respectively, while $\left(t_{2}-t_{1}\right)$ is the duration of the experiment in days. The results were expressed as increase of biomass per unit mass per day $\left(\mathrm{gg}^{-1} \mathrm{~d}^{-1}\right)$.

Calculation of enrichment $\left(E_{f}\right)$, bioaccumulation $\left(B_{f}\right)$ and translocation $\left(T_{f}\right)$ factors of heavy metals in tissues of $E$. crassipes

The enrichment factor $\left(E_{f}\right)$ of $\mathrm{Cd}, \mathrm{Cu}, \mathrm{Fe}, \mathrm{Cr}, \mathrm{Pb}, \mathrm{Zn}$ and $\mathrm{Mn}$ in the roots and leaves E. crassipes was calculated using the Equation 3 (Kim and Kim, 1999):

$$
\text { Enrichment factor }\left(\mathrm{E}_{\mathrm{f}}\right)=\frac{c_{g}}{c_{\mathrm{r}}}
$$

Where, $C_{s}$ is the mean metal concentration of treated sample and $C_{r}$ is the mean metal concentration of reference.

Bioaccumulation factor $\left(B_{f}\right)$ is the ratio of metal concentration in the plant to the metal concentration in its medium. It describes the accumulation of pollutant within the plant tissues. For plants, the $B_{f}$ is used as a measure of the efficiency of metal accumulation, whereby the value greater than 1 is the indication of plant's best potential to phytoextraction or phytoremediation (Santillan et al., 2010; Dowdy and McKone, 1997). Bioaccumulation factor was calculated using Equation 4 (Eze, 2014).

$$
\text { Bioaccumulation factor }\left(\mathrm{B}_{\mathrm{f}}\right)=\frac{c_{p}}{c_{m}}
$$

Where, $C_{p}$ is the mean metal concentration in plant tissue and $C_{m}$ is the mean metal concentration in the wastewater medium. Translocation factor $\left(T_{f}\right)$ is the screening index of hyper accumulator plants for phytoextraction of specific heavy metals. This ratio is an indication of the ability of a plant to translocate metals from its roots to its aerial parts (Mellem et al., 2012). $\mathrm{T}_{\mathrm{f}}$ was calculated by using Equation 5 .

$$
\text { Translocation factor }\left(\mathrm{T}_{\mathrm{f}}\right)=\frac{c_{L}}{c_{R}}
$$

Where, $C_{L}$ and $C_{R}$ is the concentration of metal in leaves and roots respectively.

Metals that are accumulated by plants and largely stored in the roots of the plants are indicated by $T_{f}$ values less than 1 , with values greater than 1 indicates translocation to the aerial parts of the plant (Mellem et al., 2009).

Design of anaerobic bioreactor for batch mode biogas production

A laboratory scale anaerobic bioreactor set up was designed for the bio gas production by anaerobic digestion of co-substrate. A glass aquarium $(30 \times 30 \times 30 \mathrm{~cm})$ was used as the chamber and the outer walls of the bioreactor were covered with poly-styrene plastic sheet in order to avoid the temperature loss. An aspirator glass jar of 2 liters capacity was used as a bioreactor for the digestion of different co-substrate which was placed inside the substrate digestion unit having 10 liter water. A digital temperature controller (thermostat unit) was fitted inside the substrate digestion unit to maintain the temperature of water inside the bioreactor $\left(40^{\circ} \mathrm{C}\right)$. The biomass of $E$. crassipes grown in the different concentrations of the sugar mill effluent was rinsed with distilled water and dried and then grinded with mechanical mixer to convert the biomass into granular powder. Dry powder of E. crassipes $(200 \mathrm{~g})$, sugar mill effluent $(200 \mathrm{~mL})$, cow dung $(200 \mathrm{~g})$ and $200 \mathrm{ml}$ of distilled water were mixed thoroughly to prepare the substrate slurry. The slurry was further diluted in 1:5 ratios with distilled water. 1 liter of the finally prepared sample of the co-substrate slurry was filled in the aspirator glass jar. A gas collection unit and water collection unit was also fitted in the aspirator glass bottle using IV set and rubber cork. The bioreactor was run for 15 days at $40^{\circ} \mathrm{C}$ for the anaerobic co-digestion of the substrate and generation of biogas. The quantification of biogas was performed by water displacement method per day basis. However, the theoretical estimation of methane was performed based on the reduction in the chemical oxygen demand (COD). The cumulative biogas production was 
recorded continuously till 15 days by following the standard method suggested by Goswami et al. (2016).

Characterization of physico-chemical parameters of cosubstrate

The slurry of co-substrates was analyzed for $\mathrm{pH}$, chemical oxygen demand (COD), total organic carbon (TOC), total Kjeldahl's nitrogen (TKN) and carbon/nitrogen ratio ( $\mathrm{C} / \mathrm{N}$ ratio) before and after co-digestion by following standard methods cited in APHA (2012). The total solids (TS) and volatile solids (VS) of the slurry were determined after drying a small portion of the slurry at $105^{\circ} \mathrm{C}$ for $24 \mathrm{hrs}$. (Kumar et al., 2018).

Biogas Prediction analysis using modified Gompertz kinetic model

The equation of Modified Gompertz Kinetic Model was employed to predict the cumulative biogas production and verified to fit the experimental data in order to determine some important kinetic parameters necessary for digester design and optimal operation required for large scale anaerobic plants. The equation was estimated by using nonlinear curve fitting tool, obtained by using optimization tool i.e. OriginLab Pro (version 9.1) software. Gompertz model has already been used by various authors (Atlas, 2009; Lin and Shei, 2008; Li et al., 2008) for successful prediction of maximized biogas production for a perfect lag time. This model can be expressed as Equation 6.

$$
Y_{(\mathrm{t})}=P_{\exp }\left\{-\exp \left[\frac{\mu_{\mathrm{m}}}{p}(\lambda-\mathrm{t})+1\right]\right\}
$$

Where, $\mathrm{Y}_{(\mathrm{t})}=$ Cumulative biogas production, $\mathrm{P}=$ Maximum biogas production potential, $\mu_{m}=$ Maximum specific biogas production $(\mathrm{ml}), \lambda=$ lag time (days) and $\mathrm{t}=$ Observation time of biogas production (days).

\section{Statistical analysis of the data}

The values reported in this study were the mean of three replicates. The means were calculated using MS Excel 2010 while the graphs were plotted using of OriginLab Version 9.1 and Microsoft Excel, 2010 packages. Data was statistically analyzed to determine the levels of significance using one-way analysis of variance (ANOVA).

\section{RESULTS AND DISCUSSION}

Changes in the physico-chemical and microbiological parameters of sugar mill effluent during phytoremediation

The significant changes in the various physico-chemical and microbiological parameters of sugar mill effluent E. crassipes was recorded during 60 days of phytoremediation experiment as presented in the Table 1 . The $\mathrm{pH}$ of the sugar mill effluent in different was reduced by $5.60 \%, 7.72 \%, 8.95 \%, 9.05 \%$ and $7.28 \%$ in BWW, 25, 50, 75 and 100\% treatments, respectively. The most changes in the $\mathrm{pH}$ was found maximum if the sugar mill effluent concentration was less or equal to $75 \%$. Similarly, reduction of other physico-chemical and microbiological parameters viz., EC $\left(2.25 \pm 0.04 \mathrm{dSm}^{-1}, \quad 33.55 \%\right)$, TDS (422.74 $\left.\pm 0.69 \mathrm{mgL}^{-1}, 66.98 \%\right)$, BOD $\left(94.28 \pm 0.16 \mathrm{mgL}^{-1}, 71.82 \%\right)$, COD (137.80 $\left.\pm 1.12 \mathrm{mgL}^{-1}, 76.09 \%\right)$, TKN (11.22 $\pm 0.17 \mathrm{mgL}^{-1}$, 88.22\%), P (17.57 $\left.\pm 0.16 \mathrm{mgL}^{-1}, 79.22 \%\right)$, Ca (31.01 $\pm 0.49 \mathrm{mgL}^{-1}$, 72.90\%), Mg (21.07 $\left.\pm 0.82 \mathrm{mgL}^{-1}, 76.10 \%\right), \mathrm{Na}\left(23.54 \pm 0.81 \mathrm{mgL}^{-1}\right.$, $79.24 \%)$ and $K\left(67.17 \pm 0.13 \mathrm{mgL}^{-1}, 66.71 \%\right)$ of the sugar mill effluent was observed in $75 \%$ concentration of sugar mill effluent at statistical significance of $F>$ prob $(P<0.05 / P<0.01 /$ $P<0.001)$. For the microbiological parameters of the effluent, the most reduction of $\mathrm{MPN}\left(1.059 \times 10^{3} \pm 43.15100 \mathrm{~mL}^{-1}, 66.10 \%\right)$ and SPC $\left(2.019 \times 10^{3} \pm 24.12 \mathrm{CFU} \mathrm{mL}^{-1}, 67.29 \%\right)$ was also found in the $75 \%$ treatment. Though, there was a lag phase between 0 to 15 days where the reduction was not significant $(P>0.05)$, thereafter, between 15 to 45 days or log phase, the most significant removal was observed $(P<0.05 / P<0.01 / P<0.001)$. Finally, the time between 45 to 60 days can be termed as the stationary or decline phase as there was very less or no significant reduction again in the medium. The findings of the present study are in good agreement with previous reports of Kumar and Chopra (2017) who observed higher values of TDS, BOD 5 , COD and others pollutants of sewage effluent were reduced more efficiently at $50 \%$ concentration who carried out phytoremediation using aquatic macrophyte water caltrop (Trapa natans L.). Alade and Ojoawa (2009), Akinbile and Yusoff (2012) and Kouamé et al. (2016) demonstrated reduction of COD, TKN, NO ${ }^{3-}, \mathrm{NH}_{3}$ and $\mathrm{PO}_{4}{ }^{3-}$ load from the wastewater using water hyacinth and water lettuce. Kumar et al. (2017a) reported that the water hyacinth (E. crassipes) has potentially treated the paper effluent and it can be used for the elimination of nitrogen, phosphorus, calcium, magnesium and parameters as MPN and SPC of the effluent. Dar et al. (2011) also described that water hyacinth has future prospective for the treatment of wastewater.

Reduction of heavy metals of sugar mill effluent during phytoremediation using E. crassipes

A significant $(P<0.05 / P<0.01 / P<0.001)$ reduction of heavy metals viz., $\mathrm{Cd}$ (94.99\%), $\mathrm{Pb}$ (94.44\%), $\mathrm{Zn}$ (79.70\%), $\mathrm{Cr}$ (79.31\%), $\mathrm{Mn}$ (73.13\%), $\mathrm{Cu}$ (70.67\%), Fe (66.58\%), and was noted in $75 \%$ concentration of the sugar mill effluent after 60 days of phytoremediation experiments (Table 2). The less reduction in the minimal concentration of sugar mill effluent may be subjected to the bioavailability of the net metal content in the medium as already discussed in our previous study (Kumar et al., 2017). Higher concentration of heavy metals in the medium increases its toxicity and tends to decrease plants ability to survive in such stressful conditions. These results are parallel to the findings of Dhir et al. (2009) and Kisholay and Das (2015), who found significant reduction of $\mathrm{Cd}, \mathrm{Cr}, \mathrm{Cu}, \mathrm{Fe}, \mathrm{Pb}, \mathrm{Mn}$ and $\mathrm{Zn}$ metals present in the paper mill effluent. These findings are also in accordance with Solomon and Marcus (2016) who reported that E. crassipes significantly reduced the in the content of heavy metals and others pollutants.

Occurrence of heavy metals in tissues of $\mathrm{E}$. crassipes

The contents of $\mathrm{Cd}, \mathrm{Cu}, \mathrm{Fe}, \mathrm{Cr}, \mathrm{Pb}, \mathrm{Zn}$ and $\mathrm{Mn}$ in the roots and 
Table 1. Changes in physico-chemical and microbiological characteristics of sugar mill effluent before and after phytoremediation and removal efficiency of E. crassipes in percent.

\begin{tabular}{|c|c|c|c|c|c|c|c|}
\hline \multirow{2}{*}{ Parameters } & \multirow{2}{*}{ Concentration } & \multirow{2}{*}{$\begin{array}{c}\text { Before } \\
\text { phytoremediation }\end{array}$} & \multicolumn{4}{|c|}{ After phytoremediation } & \multirow{2}{*}{$\begin{array}{c}\text { Removal } \\
(\%) \text { at } 60 \\
\text { days }\end{array}$} \\
\hline & & & 15 Days & 30 Days & 45 Days & 60 Days & \\
\hline \multirow{5}{*}{$\mathrm{pH}$} & BWW (0\%) & $7.61 \pm 0.06$ & $7.60 n s \pm 0.05$ & $7.44 n s \pm 0.02$ & $7.21 \mathrm{~ns} \pm 0.03$ & $7.19 n s \pm 0.02$ & 5.60 \\
\hline & $25 \%$ & $7.71 \pm 0.08$ & $7.60 n s \pm 0.01$ & $7.44 n s \pm 0.04$ & $7.11 \mathrm{~ns} \pm 0.02$ & $7.09 n s \pm 0.02$ & 7.96 \\
\hline & $50 \%$ & $7.76 \pm 0.07$ & $7.57 n s \pm 0.04$ & $7.24 n s \pm 0.03$ & $7.02 n s \pm 0.02$ & $7.02 n s \pm 0.02$ & 9.58 \\
\hline & $75 \%$ & $7.78 \pm 0.07$ & $7.53 n s \pm 0.03$ & $7.27 n s \pm 0.03$ & $7.06 n s \pm 0.03$ & $7.04 n s \pm 0.01$ & 7.59 \\
\hline & $100 \%$ & $7.81 \pm 0.09$ & $7.70 n s \pm 0.03$ & $7.45 n s \pm 0.04$ & $7.24 n s \pm 0.04$ & $7.22 \mathrm{~ns} \pm 0.01$ & 7.55 \\
\hline \multirow{5}{*}{$\begin{array}{c}E C \\
\left(\mathrm{dS} \mathrm{m} \mathrm{m}^{-1}\right)\end{array}$} & BWW (0\%) & $0.49 \pm 0.04$ & $0.47 n s \pm 0.04$ & $0.45 n s \pm 0.03$ & $0.40 n s \pm 0.04$ & $0.38 n s \pm 0.04$ & 22.33 \\
\hline & $25 \%$ & $1.16 \pm 0.04$ & $1.06 n s \pm 0.04$ & $1.04 n s \pm 0.03$ & $0.96 n s \pm 0.04$ & $0.95 n s \pm 0.04$ & 18.16 \\
\hline & $50 \%$ & $2.32 \pm 0.05$ & $2.19 n s \pm 0.02$ & $2.08 \mathrm{~ns} \pm 0.03$ & $1.87 n s \pm 0.03$ & $1.84 \mathrm{~ns} \pm 0.05$ & 20.83 \\
\hline & $75 \%$ & $3.48 \pm 0.06$ & $3.27 n s \pm 0.02$ & $3.07 n s \pm 0.04$ & $2.35 n s \pm 0.04$ & $2.25^{*} \pm 0.04$ & 33.55 \\
\hline & $100 \%$ & $4.64 \pm 0.07$ & $4.51 \mathrm{~ns} \pm 0.02$ & $4.24 n s \pm 0.03$ & $4.05 n s \pm 0.04$ & $4.02 n s \pm 0.01$ & 13.37 \\
\hline \multirow{5}{*}{$\begin{array}{c}\text { TDS } \\
\left(\mathrm{mg} \mathrm{L}^{-1}\right)\end{array}$} & BWW (0\%) & $144.33 \pm 0.40$ & $132.12 n s \pm 0.20$ & $110.53 n s \pm 0.85$ & $96.22 * \pm 0.42$ & $94.79 * \pm 0.54$ & 34.32 \\
\hline & $25 \%$ & $426.66 \pm 0.23$ & $392.81 \mathrm{~ns} \pm 1.52$ & $376.18 n s \pm 1.01$ & $313.08 n s \pm 1.01$ & $305.48 * \pm 0.62$ & 28.40 \\
\hline & $50 \%$ & $853.36 \pm 1.13$ & $728.41 \mathrm{~ns} \pm 1.48$ & $636.42 \mathrm{~ns} \pm 1.85$ & $563.82 \mathrm{~ns} \pm 1.20$ & $560.06^{*} \pm 0.99$ & 34.37 \\
\hline & $75 \%$ & $1280.08 \pm 2.62$ & $933.86 n s \pm 1.73$ & $804.45^{*} \pm 1.51$ & $425.56^{* *} \pm 1.24$ & $422.74^{* *} \pm 0.69$ & 66.98 \\
\hline & $100 \%$ & $1706.79 \pm 2.72$ & $1623.90 \mathrm{~ns} \pm 1.41$ & $1586.14 \mathrm{~ns} \pm 1.03$ & $1538.47 \mathrm{~ns} \pm 1.16$ & $1528.09 \mathrm{~ns} \pm 1.02$ & 10.47 \\
\hline \multirow{5}{*}{$\begin{array}{c}\mathrm{BOD} \\
\left(\mathrm{mg} \mathrm{L}^{-1}\right)\end{array}$} & BWW (0\%) & $3.13 \pm 0.05$ & $3.05 n s \pm 0.03$ & $2.63 n s \pm 0.03$ & $2.14 n s \pm 0.03$ & $2.12 \mathrm{~ns} \pm 0.02$ & 32.09 \\
\hline & $25 \%$ & $111.98 \pm 0.40$ & $95.26 n s \pm 0.19$ & $77.88 n s \pm 0.17$ & $58.63^{*} \pm 0.15$ & $55.23^{*} \pm 0.09$ & 50.68 \\
\hline & $50 \%$ & $224.04 \pm 0.60$ & $172.69 n s \pm 0.27$ & $143.28^{*} \pm 0.20$ & $111.60^{*} \pm 0.16$ & $107.28^{* *} \pm 2.66$ & 52.11 \\
\hline & $75 \%$ & $335.72 \pm 0.62$ & $229.35 n s \pm 0.53$ & $211.30 n s \pm 0.46$ & $99.44^{* *} \pm 0.24$ & $94.6^{* *} \pm 0.16$ & 71.82 \\
\hline & $100 \%$ & $447.88 \pm 4.56$ & $428.72 n s \pm 0.63$ & $401.78 n s \pm 0.62$ & $397.50 \mathrm{~ns} \pm 0.54$ & $395.96 n s \pm 0.13$ & 11.59 \\
\hline \multirow{5}{*}{$\begin{array}{c}\mathrm{COD} \\
\left(\mathrm{mg} \mathrm{L}^{-1}\right)\end{array}$} & BWW (0\%) & $8.28 \pm 0.62$ & $7.63 n s \pm 0.54$ & $7.10 n s \pm 0.08$ & $6.92 \mathrm{~ns} \pm 0.06$ & $6.90 n s \pm 0.04$ & 16.67 \\
\hline & $25 \%$ & $192.59 \pm 1.96$ & $171.46 n s \pm 1.61$ & $131.93 n s \pm 1.48$ & $103^{*} .03 \pm 1.24$ & $101.91^{*} \pm 1.20$ & 47.08 \\
\hline & $50 \%$ & $385.72 \pm 0.62$ & $289.35 n s \pm 0.53$ & $221.30 n s \pm 0.46$ & $198.72^{*} \pm 0.37$ & $191.72^{*} \pm 0.37$ & 50.30 \\
\hline & $75 \%$ & $576.23 \pm 0.66$ & $421.71 n s \pm 0.26$ & $331.53^{*} \pm 0.34$ & $142.71^{* *} \pm 0.32$ & $137.80^{* * *} \pm 0.12$ & 76.09 \\
\hline & $100 \%$ & $770.88 \pm 1.15$ & $701.14 \mathrm{~ns} \pm 1.09$ & $689.22 n s \pm 0.57$ & $666.47 n s \pm 0.33$ & $662.30 n s \pm 0.32$ & 14.08 \\
\hline \multirow{5}{*}{$\begin{array}{c}\text { TKN } \\
\left(\mathrm{mg} \mathrm{L}^{-1}\right)\end{array}$} & BWW (0\%) & $6.44 \pm 0.48$ & $5.02 \mathrm{~ns} \pm 0.27$ & $4.26 n s \pm 0.10$ & $3.88 n s \pm 0.06$ & $3.83 n s \pm 0.02$ & 40.50 \\
\hline & $25 \%$ & $33.78 \pm 0.94$ & $29.36 n s \pm 1.84$ & $22.08 \mathrm{~ns} \pm 2.95$ & $17.50 \mathrm{~ns} \pm 1.53$ & $15.17^{*} \pm 1.01$ & 55.11 \\
\hline & $50 \%$ & $67.58 \pm 1.53$ & $53.82 \mathrm{~ns} \pm 1.47$ & $44.59^{*} \pm 1.58$ & $32.43^{*} \pm 1.16$ & $28.53^{* *} \pm 0.95$ & 57.78 \\
\hline & $75 \%$ & $100.37 \pm 1.52$ & $74.75 n s \pm 1.03$ & $42.74^{*} \pm 1.51$ & $14.62^{* *} \pm 0.53$ & $11.22^{* * *} \pm 0.17$ & 88.82 \\
\hline & $100 \%$ & $135.18 \pm 1.56$ & $120.03 n s \pm 1.23$ & $112.85 n s \pm 1.47$ & $108.70 n s \pm 1.02$ & $106.07^{*} \pm 0.51$ & 21.53 \\
\hline \multirow{6}{*}{$\begin{array}{c}\mathrm{P} \\
\left(\mathrm{mg} \mathrm{L}^{-1}\right)\end{array}$} & BWW (0\%) & $3.67 \pm 0.09$ & $3.19 n s \pm 0.06$ & $2.91 \mathrm{~ns} \pm 0.07$ & $2.14 n s \pm 0.03$ & $2.11 \mathrm{~ns} \pm 0.03$ & 42.47 \\
\hline & $25 \%$ & $28.19 \pm 1.09$ & $21.79 n s \pm 1.16$ & $16.75 n s \pm 0.98$ & $13.93 n s \pm 0.43$ & $10.91^{*} \pm 0.22$ & 61.29 \\
\hline & $50 \%$ & $56.40 \pm 1.41$ & $44.35 n s \pm 0.55$ & $34.44 n s \pm 0.41$ & $26.32 * \pm 0.19$ & $21.62^{* *} \pm 0.26$ & 61.66 \\
\hline & $75 \%$ & $84.57 \pm 2.55$ & $57.15 n s \pm 2.34$ & $41.81 \mathrm{~ns} \pm 0.61$ & $21.77^{*} \pm 0.55$ & $17.57^{* * *} \pm 0.16$ & 79.22 \\
\hline & $100 \%$ & $112.79 \pm 1.54$ & $103.02 n s \pm 0.76$ & $87.02 n s \pm 0.46$ & $83.89^{*} \pm 0.31$ & $82.06 * \pm 0.06$ & 27.25 \\
\hline & BWW (0\%) & $14.22 \pm 0.50$ & $12.15 n s \pm 0.36$ & $10.61 \mathrm{~ns} \pm 0.27$ & $9.71 \mathrm{~ns} \pm 0.16$ & $9.10^{*} \pm 0.01$ & 36.01 \\
\hline & $25 \%$ & $38.15 \pm 1.23$ & $32.05 n s \pm 0.70$ & $28.65 n s \pm 0.52$ & $22.48^{*} \pm 0.44$ & $20.47^{*} \pm 0.27$ & 46.33 \\
\hline $\mathrm{Ca}$ & $50 \%$ & $76.32 \pm 1.67$ & $57.96 n s \pm 0.62$ & $53.27 n s \pm 0.21$ & $43.17^{*} \pm 0.06$ & $40.12^{*} \pm 0.06$ & 47.44 \\
\hline$\left(\mathrm{mg} \mathrm{L}^{-1}\right)$ & $75 \%$ & $114.45 \pm 1.98$ & $76.52 \mathrm{~ns} \pm 1.57$ & $61.32^{*} \pm 1.49$ & $33.06^{* *} \pm 0.86$ & $31.01^{* * *} \pm 0.49$ & 72.90 \\
\hline & $100 \%$ & $152.63 \pm 2.01$ & $146.85 n s \pm 0.81$ & $138.66 n s \pm 0.21$ & $132.18 n s \pm 0.06$ & $130.03 n s \pm 0.02$ & 13.51 \\
\hline & BWW (0\%) & $12.03 \pm 0.30$ & $10.59 n s \pm 0.18$ & $9.62 n s \pm 0.17$ & $9.07 n s \pm 0.05$ & $8.06 n s \pm 0.03$ & 33.05 \\
\hline & $25 \%$ & $29.39 \pm 0.79$ & $22.22 \mathrm{~ns} \pm 0.88$ & $17.66 n s \pm 0.83$ & $14.39^{*} \pm 0.36$ & $12.11^{*} \pm 0.33$ & 58.80 \\
\hline $\mathrm{Mg}$ & $50 \%$ & $58.80 \pm 1.01$ & $45.22 n s \pm 0.75$ & $36.55^{*} \pm 0.67$ & $29.72 * \pm 0.45$ & $27.09^{*} \pm 0.51$ & 60.25 \\
\hline$\left(\mathrm{mg} \mathrm{L}^{-1}\right)$ & $75 \%$ & $88.19 \pm .03$ & $65.77 n s \pm 0.45$ & $37.95^{*} \pm 0.35$ & $23.13^{* *} \pm 0.94$ & $21.07^{* * *} \pm 0.82$ & 76.10 \\
\hline & $100 \%$ & $117.58 \pm 1.18$ & $104.70 n s \pm 0.85$ & $96.88 n s \pm 0.42$ & $91.31 \mathrm{~ns} \pm 0.45$ & $87.75^{*} \pm 0.35$ & 25.37 \\
\hline & BWW (0\%) & $13.69 \pm 0.47$ & $11.56 n s \pm 0.32$ & $10.53 n s \pm 0.14$ & $9.56 n s \pm 0.12$ & $9.06 n s \pm 0.04$ & 33.81 \\
\hline & $25 \%$ & $37.80 \pm 1.04$ & $30.02 n s \pm 1.13$ & $24.05 n s \pm 1.03$ & $15.63^{*} \pm 0.77$ & $13.44^{*} \pm 0.63$ & 64.46 \\
\hline $\mathrm{Na}$ & $50 \%$ & $75.72 \pm 1.57$ & $52.57 n s \pm 1.09$ & 42.80ns \pm 1.08 & $30.74^{*} \pm 0.63$ & $25.59^{*} \pm 0.56$ & 66.07 \\
\hline$\left(\mathrm{mg} \mathrm{L}^{-1}\right)$ & $75 \%$ & $113.39 \pm 2.09$ & $84.42 \mathrm{~ns} \pm 1.22$ & $63.52^{*} \pm 1.50$ & $28.85^{*} \pm 1.00$ & $23.54^{* *} \pm 0.81$ & 79.24 \\
\hline & $100 \%$ & $151.38 \pm 1.97$ & $138.36 n s \pm 0.93$ & $130.46 n s \pm 0.50$ & $124.51 \mathrm{~ns} \pm 0.55$ & $123.31 \mathrm{~ns} \pm 0.09$ & 18.55 \\
\hline & BWW (0\%) & $8.73 \pm 0.37$ & $7.46 n s \pm 0.51$ & $6.97 n s \pm 0.07$ & $5.54 n s \pm 0.11$ & $5.42 \mathrm{~ns} \pm 0.09$ & 37.90 \\
\hline & $25 \%$ & $67.17 \pm 1.19$ & $52.93 n s \pm 0.52$ & $41.81 \mathrm{~ns} \pm 0.61$ & $31.54^{*} \pm 0.10$ & $31.69 * \pm 0.17$ & 52.82 \\
\hline$\frac{\mathrm{K}}{\left(\mathrm{mg} \mathrm{L}^{-1}\right)}$ & $50 \%$ & $134.35 \pm 1.45$ & $110.36 \mathrm{~ns} \pm 1.03$ & $95.16^{*} \pm 0.97$ & $63.50 * \pm 0.29$ & $62.34^{* *} \pm 0.19$ & 53.60 \\
\hline & $75 \%$ & $201.76 \pm 2.12$ & $163.86 n s \pm 1.79$ & $101.48^{*} \pm 1.36$ & $71.51^{* *} \pm 0.51$ & $67.17^{* * *} \pm 0.13$ & 66.71 \\
\hline & $100 \%$ & $268.74 \pm 1.85$ & $245.08 n s \pm 1.28$ & $235.91 \mathrm{~ns} \pm 0.77$ & $228.81 \mathrm{~ns} \pm 0.67$ & $227.66 n s \pm 0.23$ & 15.29 \\
\hline & BWW (0\%) & - & - & - & - & - & - \\
\hline & $25 \%$ & $1.04 \times 10^{3} \pm 30.57$ & $0.58 \times 10^{3^{*}} \pm 22.68$ & $0.72 \times 10^{3^{*}} \pm 19.86$ & $0.58 \times 10^{3^{*}} \pm 16.70$ & $0.56 \times 10^{3^{*}} \pm 9.85$ & 45.52 \\
\hline $\begin{array}{c}\text { MPN } \\
\left(100 \mathrm{ml}^{-1}\right)\end{array}$ & $50 \%$ & $2.085 \times 10^{3} \pm 61.25$ & $1.738 \times 10^{3^{*}} \pm 60.91$ & $1.457 \times 10^{3^{*}} \pm 42.52$ & $1.177 \times 10^{3^{*}} \pm 36.69$ & $1.135 \times 10^{3^{*}} \pm 27.07$ & 45.57 \\
\hline & $75 \%$ & $3.124 \times 10^{3} \pm 96.10$ & $2.59 \times 10^{3^{*}} \pm 87.10$ & $2.073 \times 10^{3^{* *}} \pm 66.03$ & $1.106 \times 10^{3^{* *}} \pm 59.34$ & $1.059 \times 10^{* * 3} \pm 48.82$ & 66.10 \\
\hline & $100 \%$ & $4.163 \times 10^{3} \pm 97.73$ & $3.830 \times 10^{3^{*}} \pm 86.07$ & $3.675 \times 10^{3^{*}} \pm 71.30$ & $3.505 \times 10^{3^{*}} \pm 40.08$ & $3.440 \times 10^{3^{*}} \pm 43.15$ & 55.84 \\
\hline & BWW (0\%) & - & - & - & - & - & - \\
\hline & $25 \%$ & $2.051 \times 10^{3} \pm 56.36$ & $1.753 \times 10^{3^{*}} \pm 38.16$ & $1.436 \times 10^{3^{*}} \pm 26.27$ & $1.376 \times 10^{3^{*}} \pm 30.05$ & $1.26 \times 10^{3^{* *}} \pm 37.77$ & 38.30 \\
\hline $\begin{array}{c}\mathrm{SPC} \\
\left(\mathrm{cfu} \mathrm{ml}^{-1}\right)\end{array}$ & $50 \%$ & $4.119 \times 10^{3} \pm 108.67$ & $3.536 \times 10^{3^{*}} \pm 81.74$ & $2.925 \times 10^{3^{*}} \pm 76.96$ & $2.259 \times 10^{3^{*}} \pm 53.70$ & $2.188 \times 10^{3^{* *}} \pm 37.03$ & 46.86 \\
\hline & $75 \%$ & $6.173 \times 10^{3} \pm 133.35$ & $5.460 \times 10^{3^{*}} \pm 81.74$ & $3.534 \times 10^{3^{* *}} \pm 71.08$ & $2.076 \times 10^{3^{* *}} \pm 50.85$ & $2.019 \times 10^{3^{* *}} \pm 42.12$ & 67.29 \\
\hline & $100 \%$ & $8.327 \times 10^{3} \pm 151.29$ & $7.912 \times 10^{3^{*}} \pm 77.54$ & $7.477 \times 10^{3^{*}} \pm 64.73$ & $7.350 \times 10^{3^{*}} \pm 41.71$ & $7.206 \times 10^{3^{*}} \pm 10.41$ & 13.47 \\
\hline
\end{tabular}

Values are presented in the table are the means \pm SD of three replicates; -: Non detectable; BWW (0\%): - Bore well water; ns-non significant; ${ }^{*}{ }^{* *},{ }^{* * *}$ - Significantly at $P<0.05$ or $P<0.01$ or $P<0.001$ level of ANOVA, respectively. 


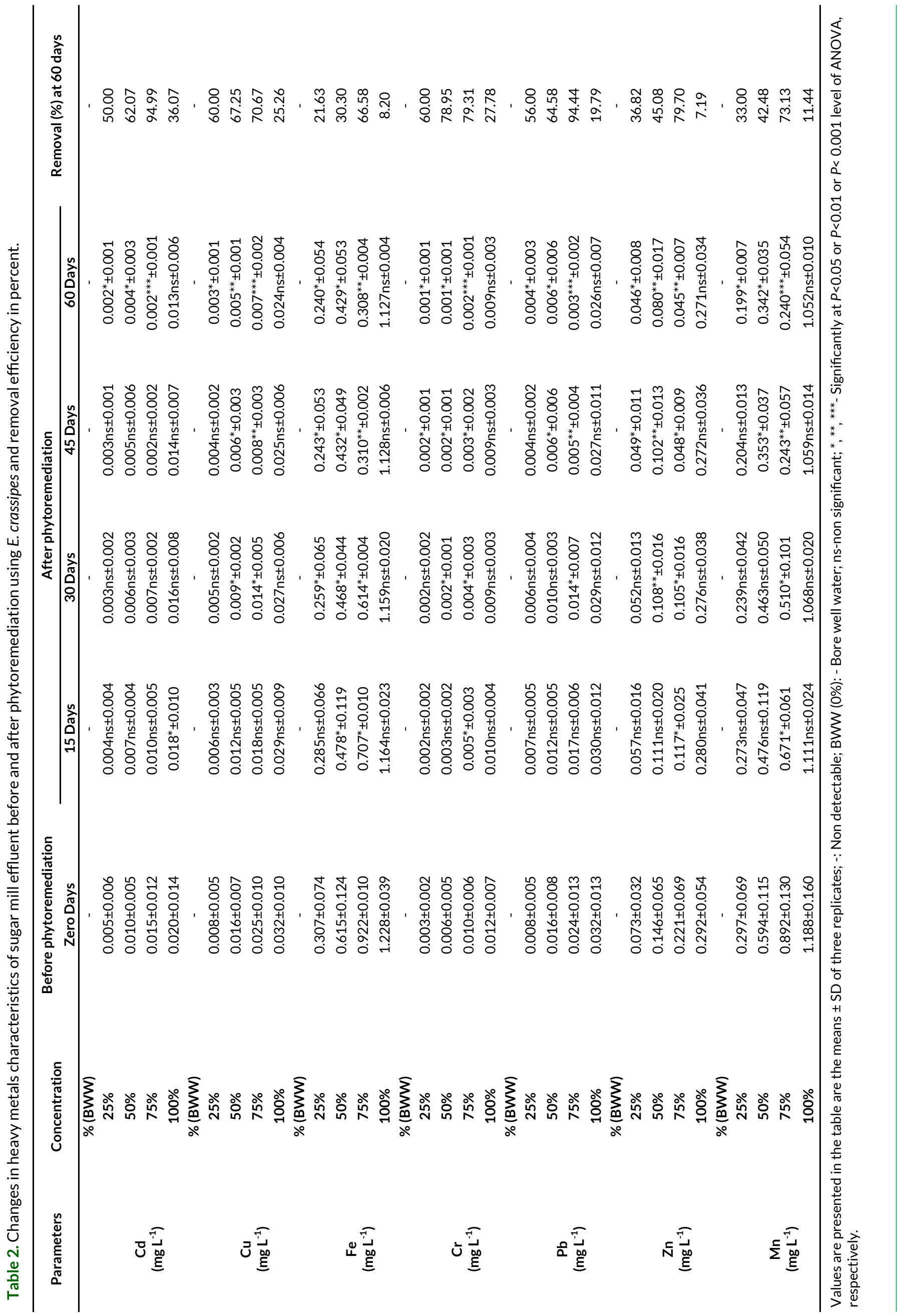


Changes in the physico-chemical parameters of co-substrate

The selected physico-chemical parameters of the substrates slurry viz., TS, COD, VS, TOC and $\mathrm{C} / \mathrm{N}$, were significantly reduced after 15 days of anaerobic digestion. The initial values of $\mathrm{pH}$ (7.88), TS (64.22\%), COD (2865 $\left.\mathrm{mgL}^{-1}\right)$, VS (58.88\%), TOC (36.54\%), TKN (1.36\%), and C/N ratio (26.86) and were found reduced to $6.22,26.98 \%, 484 \mathrm{mgL}^{-1}, 27.44 \%, 13.99 \%, 0.76 \%$ and 18.41 after 15 days of HRT at $40^{\circ} \mathrm{C}$ (Table 5). These changes occurred due to the secretion of some acids, breakdown of lignocellulosic contents, reclamation of other organic compounds and formation of other low molecular weight compounds during the anaerobic digestion process by activity of the numerous enzymes (Mathew et al., 2014; Kumar et al., 2017b). Total solid content (\%) in substrate was reduced up to $26.98 \%$ due to reduction of organic fraction present in the substrate. The most suitable condition for the anaerobic digestion process in context of digestion was at a temperature of $40^{\circ} \mathrm{C}$ as earlier reported in our another study (Kumar et al., 2018). Manjula and Mahanta (2014) also reported the similar results of total solids and volatile solids in the co-digestion of food waste and pig manure at $37^{\circ} \mathrm{C}$. The anaerobic digestion process is very effective to convert large quantities ( $>50 \%$ ) of COD present in the substrate slurry into biogas (Wilkie et al., 2000; O'Sullivan et al., 2010). COD of the substrate was decreased from $2865 \mathrm{mgL}^{-1}$ to $484 \mathrm{mgL}^{-1}$ (83.11\%) in 15 days of period at $40^{\circ} \mathrm{C}$ (Figure 14). Manjula and Mahanta (2014) observed the similar removal of COD of co-substrate during the biogas production process. O'Sullivan et al. (2010) noted the quite lower, approximately $50 \%$ reduction in COD during the utilization of dairy effluents in biogas production. Moreover, the best percentile reduction in COD may be subjected to a higher retention time as the COD reduction increase with increasing HRT (Bhadouria and Sai, 2011). The $\mathrm{C} / \mathrm{N}$ ratio was altered from 26.86 to 18.41 . The ideal $\mathrm{C} / \mathrm{N}$ ratio for anaerobic digestion is considered to be in the range of 20-30 C/N ratio (Doraisamy et al., 2013; Kumar et al., 2017b). The high $\mathrm{C} / \mathrm{N}$ ratio refers the rapid consumption of nitrogen by the methanogenic bacteria to meet their protein requirement and as a result, the biogas production was reduced (Wang et al., 2014). When $\mathrm{pH}$ value rose higher than 8.5 , it begins to exert a toxic effect on the methanogenic bacteria (Wilkie et al., 2000). Generally, to maintain the $\mathrm{C} / \mathrm{N}$ level of the digester substrate at optimum levels, substrate of high $\mathrm{C} / \mathrm{N}$ ratio can be co-digested with substrate of low $\mathrm{C} / \mathrm{N}$ ratio (Sawant et al., 2007). The total Kjeldhal nitrogen (TKN) and total organic carbon (TOC) of the substrate such as $1.36 \%-0.76$ and $36.54 \%$ - $13.39 \%$ was observed after digestion process for the production of biogas. The similar results were reported by Kumar et al. (2017b).

Prediction analysis for biogas production using modified Gompertz kinetic model

Biogas production was monitored using water displaced method and measured until there was no more biogas production. The modified Gompertz model was used to estimate the fitness for prediction of cumulative biogas production. Results showed that the cumulative biogas production $(5195 \mathrm{~mL})$ and using modified Gompertz kinetic model $(5238.71 \mathrm{~mL})$ were achieved after 15 days of anaerobic digestion (Figure 15). The value of different kinetic parameters for the model viz., a,xc and k were 6096.12, 7.73 and 0.26 , respectively with $\mathrm{R}^{2}$ (coefficient of determination) value of 0.99 . The modified Gompertz model gave the satisfactory result in predicting biogas production for all variables as earlier reported by previous findings by Budiyono et al. (2014) and Kumar et al. (2018).

\section{Kinetics of co-substrate COD reduction}

The kinetics of COD reduction was studied by applying a first order kinetic equation, by plotting $\log (\mathrm{COD}) \mathrm{vs.} t$ (HRT) which showed the good of fitting correlation coefficient $\left(R^{2}=0.9594\right)$ as presented in Figure 15. The reduction pattern of COD indicates the effectiveness of methanogenic activity and the temperature near to $40^{\circ} \mathrm{C}$ may also be termed as optimum for mesophilic condition where the best condition for maximum COD reduction was observed. The values of the rate constant and $\mathrm{R}^{2}$ were 0.0337 and 0.9746 , respectively. These results are in good agreement with the findings of Samuel et al. (2017) who reported the good fitness of first order kinetic equation to evaluate the COD reduction during biogas production.
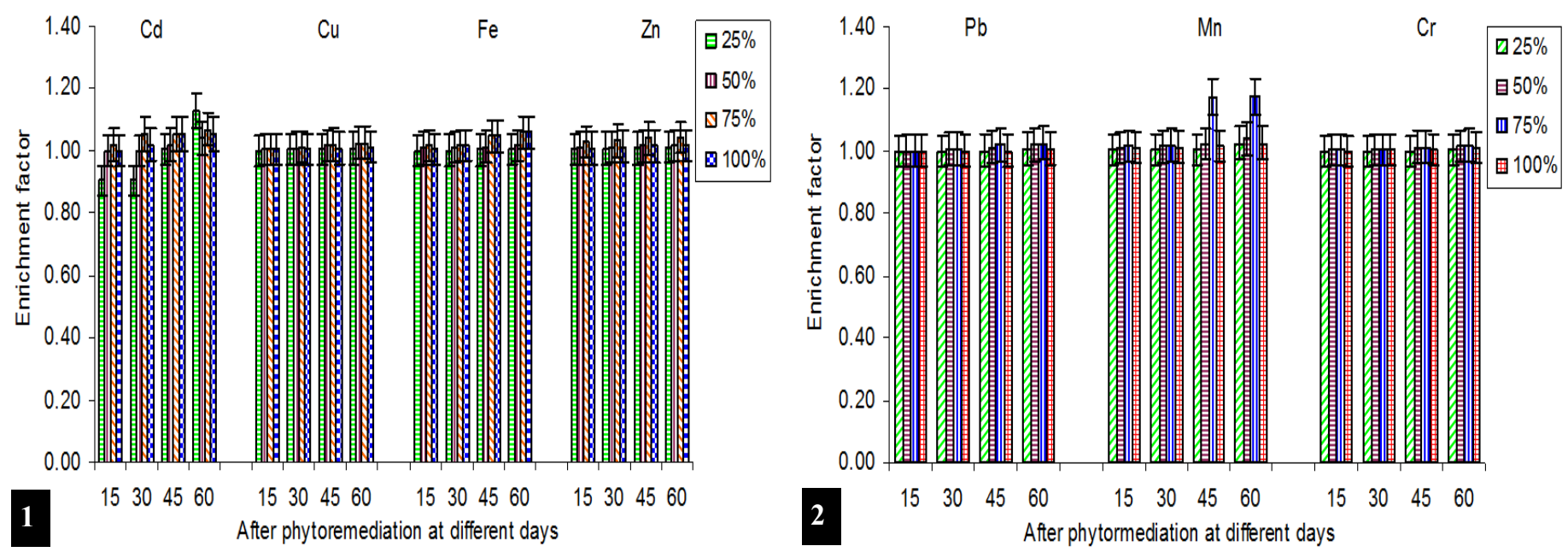

Figure 1-2. Enrichment factor $\left(E_{f}\right)$ of different heavy metals in the roots of $E$. crassipes after phytoremediation at different days. 
leaves of E. crassipes were progressively enhanced from 15 to 45 days as the maximum uptake was occurred during this period. We observed significant $(P<0.05 / P<0.01)$ enrichment of different heavy metals in the roots and leaves of $E$. crassipes as presented in Tables 3 and 4. The quantity of different heavy metals in the roots and leaves of E. crassipes were observed highest in $75 \%$ concentration of the sugar mill effluent. However, the order of their accumulation as per quantity was noted in the order of $\mathrm{Fe}>\mathrm{Mn}>\mathrm{Zn}>\mathrm{Cu}>\mathrm{Cr}>\mathrm{Pb}>\mathrm{Cd}$. The diverse absorption and accumulation of different heavy metals indicated speckled uptake due to self-protection mechanism of the E. crassipes against different metals depends on the affinity of these metals in different physiological processes, growth and development. In the similar way, the varied accumulation of different metals in the tissues of Eichhornia, Pistia, Lemna, and Vallisneria aquatic plants has also been reported by Sharma et al. (2004) and Kumar et al. (2016) which supports the data of this study.

\section{Enrichment of heavy metals in tissues of E. crassipes}

Generally, the hyper accumulator plant having enrichment factor $\left(E_{f}\right)$ values greater than or equal to $1\left(E_{f} \geq 1\right)$ tells that the selected plant is decent for phytoremediation process. It also indicates that the plant has high capability of to accumulate and tolerate toward higher concentration of heavy metals in its medium. In this study, Figures 1-2 and 3-4 shows the enrichment factor of different heavy metals in the roots and leaves of $E$. crassipes grown in sugar mill effluent amended at different concentrations, respectively. The results revealed that the heavy metals enrichment in the root of E. crassipes was observed high as compared to the leaf parts. The order of heavy metal enrichment for roots was observed as $\mathrm{Mn}>\mathrm{Cd}>\mathrm{Fe}>\mathrm{Zn}>\mathrm{Cu}>\mathrm{Pb}>\mathrm{Cr}$; while for leaves it was found as $\mathrm{Cd}>\mathrm{Fe}>\mathrm{Mn}>\mathrm{Zn}>\mathrm{Pb}>\mathrm{Cu}>\mathrm{Cr}$. This defines that $E$. crassipes has varied heavy metal enrichment behavior toward several metals, as; a few of them easily enriched in the root parts while some are not. Similarly, for leaf parts some metals were actively transported to the leaf easily, while, some were retained in the roots. This might be due to the affinity of plant towards the transportation of the heavy metals from roots to leaves, which is related with the biochemistry of the plant, where special plant proteins together bind with heavy metals and further transport them through the plant body. Srivastava et al. (2014) reported varied enrichment factor of different heavy metals in the tissues of the plant of E. crassipes as $\mathrm{Cr}>\mathrm{Fe}>\mathrm{Cu}>\mathrm{Mn}>\mathrm{Mg}$, when grown in Sulem Sarai wetland of Allahabad, Uttar Pradesh, India. They reported that $E_{f}$ of different heavy metals extended 1.02 to 1.07 in roots of $E$. crassipes whereas 1.02 to 1.85 in the leaves of E. crassipes during phytoremediation, which is in good agreement with the results of present study.

Bioaccumulation of heavy metals in the tissues of $E$. crassipes The bioaccumulation by the plants is defined as their capability to accumulate heavy metals into their different body parts, however, it is strongly affected by numerous external as well as internal factors like; nutrient availability, plant metabolism and microbial growth in the medium (Chandra et al., 2017). Figures 5 -6 and 7-8 represents the bioaccumulation factor $\left(B_{f}\right)$ of different heavy metals accumulated in the roots and leaves of $E$. crassipes, respectively. We found that maximum bioaccumulation of all selected heavy metals were observed in the $75 \%$ concentration of sugar mill effluent. However, the order of their bioaccumulation was varied as $\mathrm{Cr}>\mathrm{Fe}>\mathrm{Cu}>\mathrm{Mn}>\mathrm{Mg}$ for roots and $\mathrm{Cr}>\mathrm{Fe}>\mathrm{Cu}>\mathrm{Mn}>\mathrm{Mg}$ for leaves, respectively. The $\mathrm{B}_{\mathrm{f}}$ value of all heavy metals was greater than $1(<1)$ which showed good potential of $E$. crassipes for the removal heavy metals which supports to consider this as hyper-accumulative plant for phytoremediation purposes (Santillan et al., 2010). Mellem (2009) and Chandra et al. (2017) reported the $B_{f}$ values viz., 1-2 and conferring E. crassipes having high ability to accumulate heavy metals from the contaminated water bodies.

Translocation of heavy metals in the tissues of E. crassipes The transportation of heavy metals from roots to leaves of $E$. crassipes is due to nutritional and metabolic requirements, which is strongly regulated by the several physiological and biochemical processes (Chandra et al., 2017). Data in the Figures 9-10 shows the translocation factor $\left(T_{f}\right)$ of selected heavy metals from roots to leaves of $E$. crassipes. It was observed that the translocation factor reached maximum in $75 \%$ concentration of the sugar mill effluent with an elemental order of $\mathrm{Cd}>\mathrm{Zn}>\mathrm{Pb}>\mathrm{Fe}>\mathrm{Cr}>\mathrm{Mn}>\mathrm{Cu}$, respectively. Similarly, previous study carried out by Chandra et al. (2017) also reported the translocation factor of selected plant greater 1 when used for phytoremediation of pulp and paper industry effluent.

Changes in plant growth parameters of E. Crassipes during phytoremediation

Figures 11-13 shows the kinetic growth rate, total plant fresh biomass and total chlorophyll content of $E$. crassipes grown different concentration of sugar mill effluent, respectively. The maximum values of kinetic growth rate $\left(2.56 \mathrm{gg}^{-1} \mathrm{~d}^{-1}\right)$, total fresh plant biomass $(339.87 \pm 4.64 \mathrm{~g} / \mathrm{kg})$ and total chlorophyll content $(4.10 \pm 0.10 \mathrm{mg} / \mathrm{gfwt})$ were observed highest in $75 \%$ concentration (Figures 11-13). This might be due to the presence of the favorable concentration of different plant nutrients in the sugar mill effluent which trigged the plant growth to reach maximum as earlier reported by (Sooknah and Wilkie, 2014; Kumar et al., 2016). However, in the $100 \%$ concentration treatment, the plant growth was progressively declined after 45-60 days as compared to other treatments, which may be due to metal induced inhibition of physiological processes and biosynthesis (Mukherjee and Kumar, 2005). A similar type of reduction in the total chlorophyll content of water lettuce was reported in a previous study and concluded that it was due to the presence of $\mathrm{Hg}$ toxicity in the wastewater (De et al., 1985), Cd and Hg treatment by Hydrilla verticillata and Lemna minor (Chatterjee and $\mathrm{Nag}, 1991$ ), $\mathrm{Pb}$ treated by the Salvina natans (Sen and Bhattacharyya, 1993), $\mathrm{Pb}$ and $\mathrm{Cr}$ treatment by Ipomea aquatica (Alam and Chatterjee, 1994) and $\mathrm{Zn}, \mathrm{Cu}, \mathrm{Cd}$ and $\mathrm{Cr}$ treatment of wastewater using water hyacinth and water lettuce (Kouamé et al., 2016). 


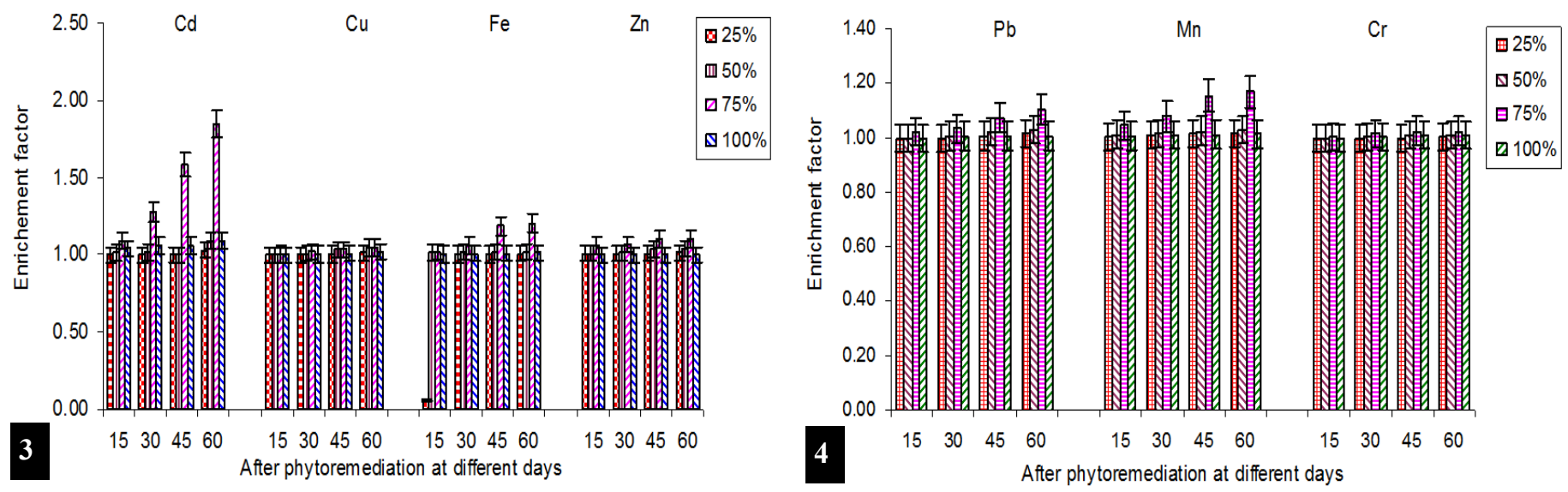

Figure 3-4. Enrichment factor $\left(E_{f}\right)$ of different heavy metals in the leaves of $E$. crassipes after phytoremediation at different days.
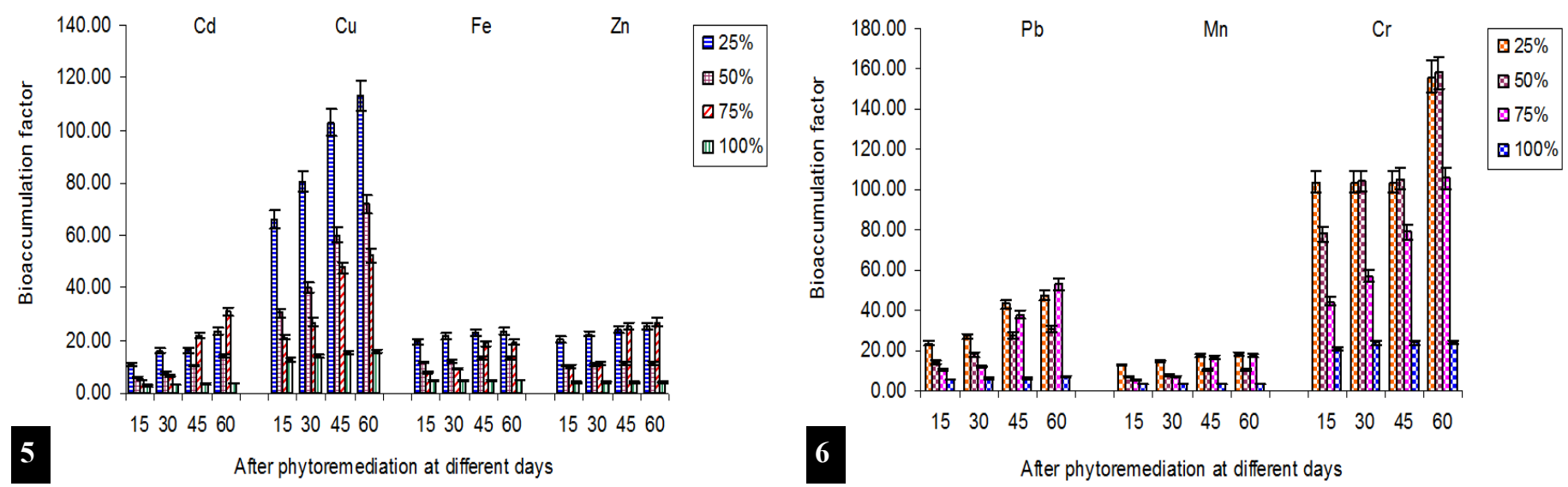

Figure 5-6. Bioaccumulation factor $\left(B_{f}\right)$ of different heavy metals in the roots of E. crassipes after phytoremediation at different days

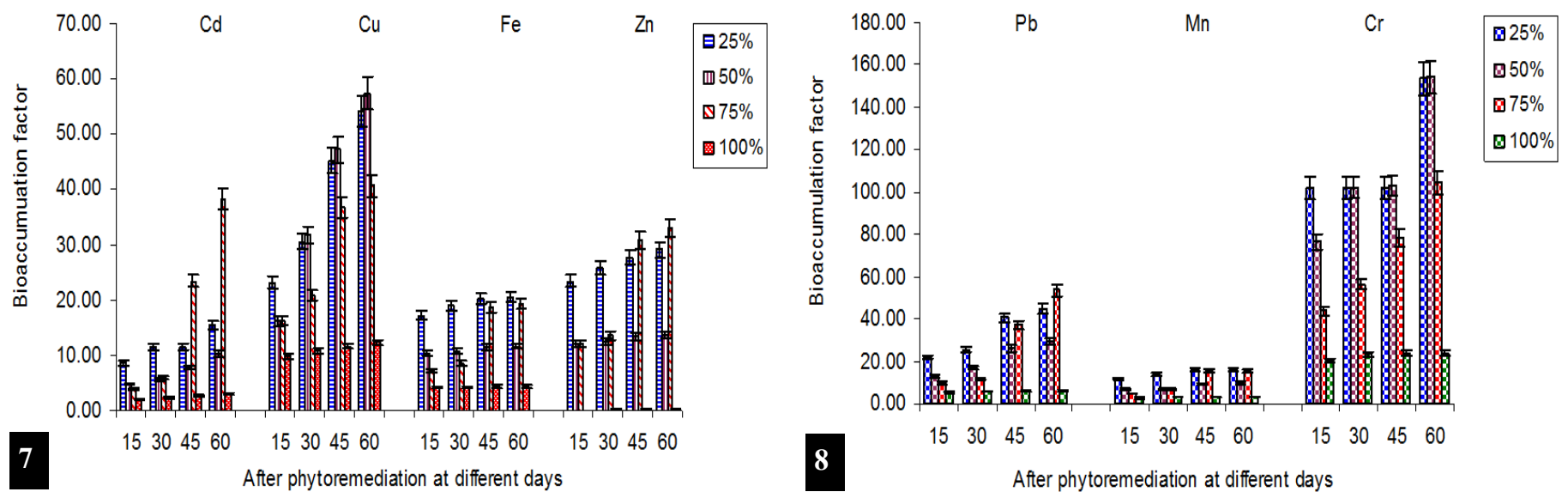

Figure 7-8. Bioaccumulation factor $\left(B_{f}\right)$ of different heavy metals in the leaves of E. crassipes after phytoremediation at different days.
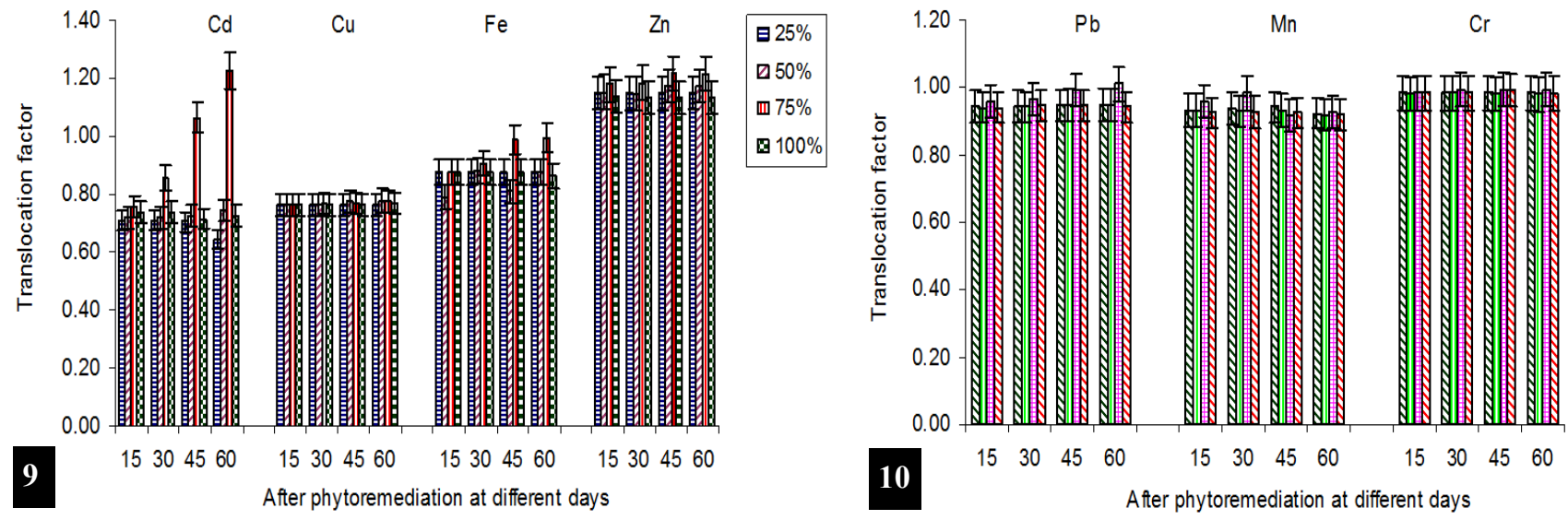
Table 3. Heavy metals concentration in roots of E. crassipes before and after phytoremediation grown in sugar mill effluent.

\begin{tabular}{|c|c|c|c|c|c|c|}
\hline \multirow{2}{*}{ Parameters } & \multirow{2}{*}{ Concentration } & \multicolumn{5}{|c|}{ After phytoremediation } \\
\hline & & Zero days & 15 days & 30 days & 45 days & 60 days \\
\hline \multirow{5}{*}{$\underset{(\mathrm{mg} / \mathrm{kg})}{\mathrm{Cd}}$} & \% (BWW) & \multirow{5}{*}{$0.049 \pm 0.006$} & - & - & - & - \\
\hline & $25 \%$ & & $0.049 n s \pm 0.006$ & $0.049 n s \pm 0.006$ & $0.051 \mathrm{~ns} \pm 0.005$ & $0.050 \mathrm{~ns} \pm 0.003$ \\
\hline & $50 \%$ & & $0.049 n s \pm 0.006$ & $0.049 n s \pm 0.006$ & $0.050 \mathrm{~ns} \pm 0.005$ & $0.051 \mathrm{~ns} \pm 0.008$ \\
\hline & $75 \%$ & & $0.050 \mathrm{~ns} \pm 0.005$ & $0.051 \mathrm{~ns} \pm 0.007$ & $0.051 \mathrm{~ns} \pm 0.007$ & $0.052^{*} \pm 0.008$ \\
\hline & $100 \%$ & & $0.049 n s \pm 0.005$ & $0.050 n s \pm 0.006$ & $0.051 \mathrm{~ns} \pm 0.008$ & $0.052^{*} \pm 0.008$ \\
\hline \multirow{4}{*}{$\underset{(\mathrm{mg} / \mathrm{kg})}{\mathrm{Cu}}$} & $\%$ (BWW) & \multirow{4}{*}{$0.375 \pm 0.004$} & - & - & - & - \\
\hline & $25 \%$ & & $0.375 n s \pm 0.004$ & $0.376 n s \pm 0.006$ & $0.377 n s \pm 0.006$ & $0.378 n s \pm 0.008$ \\
\hline & $50 \%$ & & $0.376 n s \pm 0.006$ & $0.378 n s \pm 0.007$ & $0.382 \mathrm{~ns} \pm 0.007$ & $0.385^{*} \pm 0.010$ \\
\hline & $75 \%$ & & $0.377 n s \pm 0.006$ & $0.379 n s \pm 0.008$ & $0.383 n s \pm 0.009$ & $0.384^{*} \pm 0.010$ \\
\hline \multirow{6}{*}{$\begin{array}{c}\mathrm{Fe} \\
(\mathrm{mg} / \mathrm{kg})\end{array}$} & $100 \%$ & \multirow{6}{*}{$5.613 \pm 0.057$} & $0.376 n s \pm 0.006$ & $0.377 n s \pm 0.006$ & $0.378 n s \pm 0.007$ & $0.379 \mathrm{~ns} \pm 0.008$ \\
\hline & $\%(B W W)$ & & - & - & - & - \\
\hline & $25 \%$ & & $5.618 \mathrm{~ns} \pm 0.060$ & $5.625 n s \pm 0.057$ & $5.630 \mathrm{~ns} \pm 0.053$ & $5.635 n s \pm 0.059$ \\
\hline & $50 \%$ & & $5.663 n s \pm 0.058$ & $5.673 n s \pm 0.067$ & $5.694 \mathrm{~ns} \pm 0.074$ & $5.703 n s \pm 0.083$ \\
\hline & $75 \%$ & & $5.703 n s \pm 0.088$ & $5.713 n s \pm 0.098$ & $5.884^{*} \pm 0.077$ & $5.948^{*} \pm 0.069$ \\
\hline & $100 \%$ & & $5.637 n s \pm 0.062$ & $5.639 n s \pm 0.064$ & $5.653 n s \pm 0.081$ & $5.759 n s \pm 0.069$ \\
\hline \multirow{5}{*}{$\underset{(\mathrm{mg} / \mathrm{kg})}{\mathrm{Zn}}$} & \% (BWW) & \multirow{5}{*}{$1.164 \pm 0.013$} & - & - & - & - \\
\hline & $25 \%$ & & $1.171 \mathrm{~ns} \pm 0.010$ & $1.173 n s \pm 1.346$ & $1.174 n s \pm 1.347$ & $1.175 \mathrm{~ns} \pm 1.349$ \\
\hline & $50 \%$ & & $1.174 \mathrm{~ns} \pm 1.174$ & $1.179 n s \pm 1.179$ & $1.181 \mathrm{~ns} \pm 1.181$ & $1.183^{*} \pm 1.183$ \\
\hline & $75 \%$ & & $1.198^{*} \pm 0.015$ & $1.203^{*} \pm 0.026$ & $1.210^{*} \pm 0.030$ & $1.213^{*} \pm 0.035$ \\
\hline & $100 \%$ & & $1.173 n s \pm 0.012$ & $1.180 n s \pm 0.013$ & $1.182 \mathrm{~ns} \pm 0.011$ & $1.183^{*} \pm 0.013$ \\
\hline \multirow{5}{*}{$\begin{array}{c}\mathrm{Pb} \\
(\mathrm{mg} / \mathrm{kg})\end{array}$} & \% (BWW) & \multirow{5}{*}{$0.172 \pm 0.008$} & - & - & - & - \\
\hline & $25 \%$ & & $0.172 \mathrm{~ns} \pm 0.008$ & $0.172 n s \pm 0.008$ & $0.173 n s \pm 0.009$ & $0.174 n s \pm 0.010$ \\
\hline & $50 \%$ & & $0.173 n s \pm 0.009$ & $0.174 n s \pm 0.010$ & $0.175 n s \pm 0.011$ & $0.176 n s \pm 0.012$ \\
\hline & $75 \%$ & & $0.173 n s \pm 0.009$ & $0.174 n s \pm 0.010$ & $0.176^{*} \pm 0.012$ & $0.177^{*} \pm 0.013$ \\
\hline & $100 \%$ & & $0.173 n s \pm 0.009$ & $0.173 n s \pm 0.009$ & $0.173 n s \pm 0.009$ & $0.174 n s \pm 0.010$ \\
\hline \multirow{4}{*}{$\begin{array}{c}\mathrm{Mn} \\
(\mathrm{mg} / \mathrm{kg})\end{array}$} & \% (BWW) & \multirow{5}{*}{$3.490 \pm 0.022$} & - & - & - & - \\
\hline & $25 \%$ & & $3.502 n s \pm 0.087$ & $3.502 \mathrm{~ns} \pm 0.087$ & $3.506 n s \pm 0.089$ & $3.581^{*} \pm 0.097$ \\
\hline & $50 \%$ & & $3.530 \mathrm{~ns} \pm 0.048$ & $3.545 n s \pm 0.075$ & $3.573^{*} \pm 0.093$ & $3.636^{*} \pm 0.110$ \\
\hline & $75 \%$ & & $3.547 n s \pm 0.076$ & $3.557 n s \pm 0.081$ & $4.090^{* *} \pm 0.084$ & $4.101^{* *} \pm 0.086$ \\
\hline \multirow{6}{*}{$\begin{array}{c}\mathrm{Cr} \\
(\mathrm{mg} / \mathrm{kg})\end{array}$} & $100 \%$ & & $3.530 \mathrm{~ns} \pm 0.048$ & $3.539 n s \pm 0.071$ & $3.555 \mathrm{~ns} \pm 0.077$ & $3.582^{*} \pm 0.084$ \\
\hline & \% (BWW) & \multirow{5}{*}{$0.207 \pm 0.004$} & - & - & - & - \\
\hline & $25 \%$ & & $0.207 n s \pm 0.004$ & $0.207 n s \pm 0.005$ & $0.207 n s \pm 0.005$ & $0.208 n s \pm 0.006$ \\
\hline & $50 \%$ & & $0.208 n s \pm 0.004$ & $0.208 n s \pm 0.005$ & $0.210 \mathrm{~ns} \pm 0.006$ & $0.211^{*} \pm 0.007$ \\
\hline & $75 \%$ & & $0.208 n s \pm 0.005$ & $0.208 n s \pm 0.005$ & $0.210 \mathrm{~ns} \pm 0.006$ & $0.210 \mathrm{~ns} \pm 0.006$ \\
\hline & $100 \%$ & & $0.207 n s \pm 0.004$ & $0.208 n s \pm 0.004$ & $0.208 n s \pm 0.005$ & $0.210 n s \pm 0.006$ \\
\hline
\end{tabular}

Values are presented in the table are the means \pm SD of three replicates; -: Non detectable; BWW (0\%): - Bore well water; ns-non significant; *, ${ }^{* *},{ }^{* * *}$ - Significantly at $\mathrm{P}<0.05$ or $\mathrm{P}<0.01$ or $\mathrm{P}<0.001$ level of ANOVA, respectively.

Table 4. Heavy metals concentration in leaves of $E$. crassipes before and after phytoremediation grown in sugar mill effluent.

\begin{tabular}{|c|c|c|c|c|c|c|}
\hline \multirow{2}{*}{ Parameters } & \multirow{2}{*}{ Concentration } & \multicolumn{5}{|c|}{ After phytoremediation } \\
\hline & & Zero days & 15 days & 30 days & 45 days & 60 days \\
\hline \multirow{5}{*}{$\underset{(\mathrm{mg} / \mathrm{kg})}{\mathrm{Cd}}$} & \% (BWW) & \multirow{5}{*}{$0.035 \pm 0.004$} & - & - & - & - \\
\hline & $25 \%$ & & $0.035 n s \pm 0.004$ & $0.035 n s \pm 0.005$ & $0.035 n s \pm 0.005$ & $0.036 n s \pm 0.006$ \\
\hline & $50 \%$ & & $0.035 n s \pm 0.005$ & $0.035 n s \pm 0.005$ & $0.036 n s \pm 0.006$ & $0.038 \mathrm{~ns} \pm 0.007$ \\
\hline & $75 \%$ & & $0.038 n s \pm 0.007$ & $0.044^{*} \pm 0.010$ & $0.055( \pm 0.011$ & $0.064^{*} \pm 0.013$ \\
\hline & $100 \%$ & & $0.036 n s \pm 0.005$ & $0.037 n s \pm 0.005$ & $0.037 n s \pm 0.005$ & $0.038 n s \pm 0.005$ \\
\hline \multirow{5}{*}{$\underset{(\mathrm{mg} / \mathrm{kg})}{\mathrm{Cu}}$} & \% (BWW) & \multirow{5}{*}{$0.285 \pm 0.004$} & - & - & - & - \\
\hline & $25 \%$ & & $0.285 n s \pm 0.004$ & $0.286 n s \pm 0.004$ & $0.287 n s \pm 0.005$ & $0.289 n s \pm 0.005$ \\
\hline & $50 \%$ & & $0.286 n s \pm 0.005$ & $0.288 n s \pm 0.006$ & $0.295 n s \pm 0.007$ & $0.299^{*} \pm 0.010$ \\
\hline & $75 \%$ & & $0.287 n s \pm 0.004$ & $0.292 \mathrm{~ns} \pm 0.005$ & $0.295 n s \pm 0.012$ & $0.298^{*} \pm 0.013$ \\
\hline & $100 \%$ & & $0.286 n s \pm 0.005$ & $0.287 n s \pm 0.005$ & $0.288 n s \pm 0.006$ & $0.291 \mathrm{~ns} \pm 0.004$ \\
\hline \multirow{5}{*}{$\begin{array}{c}\mathrm{Fe} \\
(\mathrm{mg} / \mathrm{kg})\end{array}$} & \% (BWW) & \multirow{5}{*}{$4.905 \pm 0.056$} & - & - & - & - \\
\hline & $25 \%$ & & $4.921 \mathrm{~ns} \pm 0.049$ & $4.923 n s \pm 0.049$ & $4.930 n s \pm 0.049$ & $4.944 n s \pm 0.049$ \\
\hline & $50 \%$ & & $4.975 n s \pm 0.513$ & $4.998 n s \pm 0.461$ & $4.999^{*} \pm 0.462$ & $4.999 * \pm 0.462$ \\
\hline & $75 \%$ & & $5.005^{*} \pm 0.003$ & $5.185^{*} \pm 0.028$ & $5.820^{*} \pm 0.074$ & $5.911^{* *} \pm 0.055$ \\
\hline & $100 \%$ & & $4.930 \pm 0.044$ & $4.939 \pm 0.044$ & $4.947 \pm 0.033$ & $4.956 \pm 0.022$ \\
\hline \multirow{5}{*}{$\underset{(\mathrm{mg} / \mathrm{kg})}{\mathrm{Zn}}$} & \% (BWW) & \multirow{5}{*}{$1.336 \pm 0.003$} & - & - & - & - \\
\hline & $25 \%$ & & $1.346 n s \pm 0.009$ & $1.346 n s \pm 0.009$ & $1.347 n s \pm 0.007$ & $1.349 \mathrm{~ns} \pm 0.007$ \\
\hline & $50 \%$ & & $1.346 \mathrm{~ns} \pm 0.009$ & $1.351 \mathrm{~ns} \pm 0.009$ & $1.387 n s \pm 0.011$ & $1.390^{*} \pm 0.008$ \\
\hline & $75 \%$ & & $1.412^{*} \pm 0.035$ & $1.424^{*} \pm 0.055$ & $1.472^{*} \pm 0.062$ & $1.473^{*} \pm 0.065$ \\
\hline & $100 \%$ & & $1.337 n s \pm 0.003$ & $1.338 n s \pm 0.005$ & $1.338 \mathrm{~ns} \pm 0.005$ & $1.339 n s \pm 0.006$ \\
\hline \multirow{5}{*}{$\begin{array}{c}\mathrm{Pb} \\
(\mathrm{mg} / \mathrm{kg})\end{array}$} & \% (BWW) & \multirow{5}{*}{$0.162 \pm 0.007$} & - & - & - & - \\
\hline & $25 \%$ & & $0.162 \mathrm{~ns} \pm 0.007$ & $0.162 \mathrm{~ns} \pm 0.007$ & $0.163 n s \pm 0.009$ & $0.165 n s \pm 0.010$ \\
\hline & $50 \%$ & & $0.162 \mathrm{~ns} \pm 0.007$ & $0.163 n s \pm 0.009$ & $0.166 n s \pm 0.011$ & $0.167 n s \pm 0.012$ \\
\hline & $75 \%$ & & $0.166 n s \pm 0.011$ & $0.168 n s \pm 0.012$ & $0.174^{*} \pm 0.009$ & $0.179 * \pm 0.010$ \\
\hline & $100 \%$ & & $0.162 \mathrm{~ns} \pm 0.007$ & $0.163 n s \pm 0.009$ & $0.163 n s \pm 0.009$ & $0.163 n s \pm 0.009$ \\
\hline \multirow{4}{*}{$\underset{(\mathrm{mg} / \mathrm{kg})}{\mathrm{Mn}}$} & \% (BWW) & \multirow{5}{*}{$3.248 \pm 0.060$} & - & - & - & - \\
\hline & $25 \%$ & & $3.263 \mathrm{~ns} \pm 0.071$ & $3.283 n s \pm 0.079$ & $3.297 n s \pm 0.080$ & $3.302^{*} \pm 0.094$ \\
\hline & $50 \%$ & & $3.288 n s \pm 0.073$ & $3.298 n s \pm 0.079$ & $3.328^{*} \pm 0.085$ & $3.340^{*} \pm 0.098$ \\
\hline & $75 \%$ & & $3.398^{*} \pm 0.076$ & $3.498^{*} \pm 0.097$ & $3.748^{*} \pm 0.088$ & $3.798^{*} \pm 0.101$ \\
\hline \multirow{6}{*}{$\underset{(\mathrm{mg} / \mathrm{kg})}{\mathrm{Cr}}$} & $100 \%$ & & $3.268 n s \pm 0.070$ & $3.278 n s \pm 0.095$ & $3.290 \mathrm{~ns} \pm 0.115$ & $3.293 n s \pm 0.118$ \\
\hline & \% (BWW) & \multirow{5}{*}{$0.204 \pm 0.003$} & - & - & - & - \\
\hline & $25 \%$ & & $0.204 n s \pm 0.003$ & $0.204 n s \pm 0.003$ & $0.204 n s \pm 0.003$ & $0.205 n s \pm 0.004$ \\
\hline & $50 \%$ & & $0.204 n s \pm 0.004$ & $0.205 n s \pm 0.004$ & $0.206 n s \pm 0.004$ & $0.206 n s \pm 0.005$ \\
\hline & $75 \%$ & & $0.205 n s \pm 0.004$ & $0.207 n s \pm 0.005$ & $0.209^{*} \pm 0.006$ & $0.209^{*} \pm 0.006$ \\
\hline & $100 \%$ & & $0.204 n s \pm 0.003$ & $0.205 n s \pm 0.003$ & $0.206 n s \pm 0.004$ & $0.206 n s \pm 0.005$ \\
\hline
\end{tabular}

Values are presented in the table are the means \pm SD of three replicates; -: Non detectable; BWW (0\%): - Bore well water; ns-non significant; ${ }^{*}{ }^{* *},{ }^{* * *}$ - Significantly at $\mathrm{P}<0.05$ or $\mathrm{P}<0.01$ or $\mathrm{P}<0.001$ level of ANOVA, respectively. 


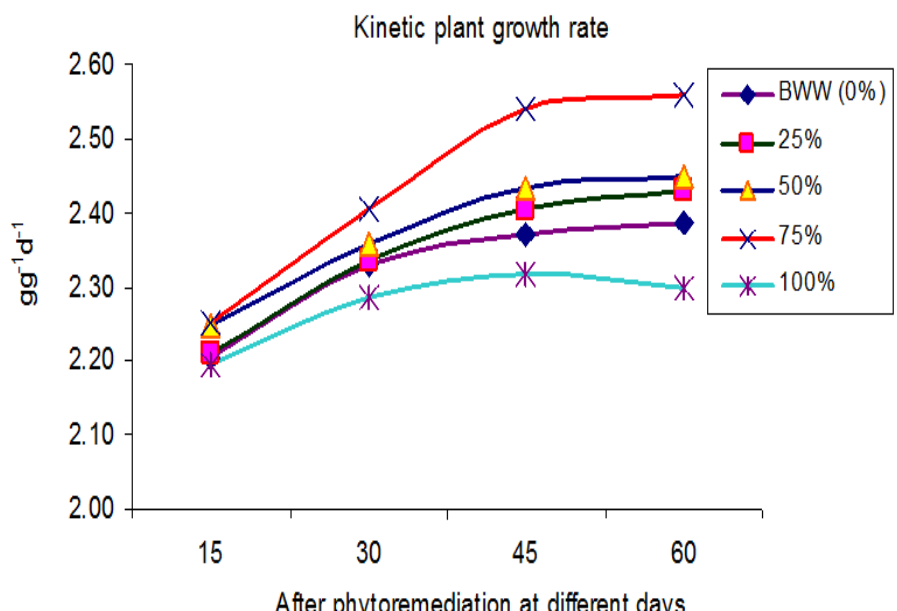

Figure 11. Kinetic growth rate (KGR) of E. crassipes after phytoremediation at different days.

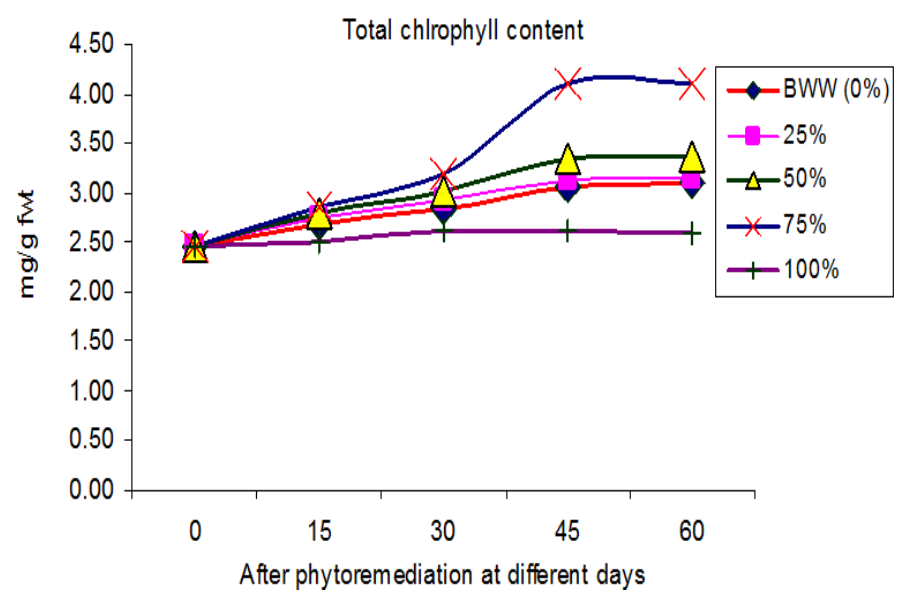

Figure 13. Total chlorophyll content of E. crassipes after phytoremediation at different days.

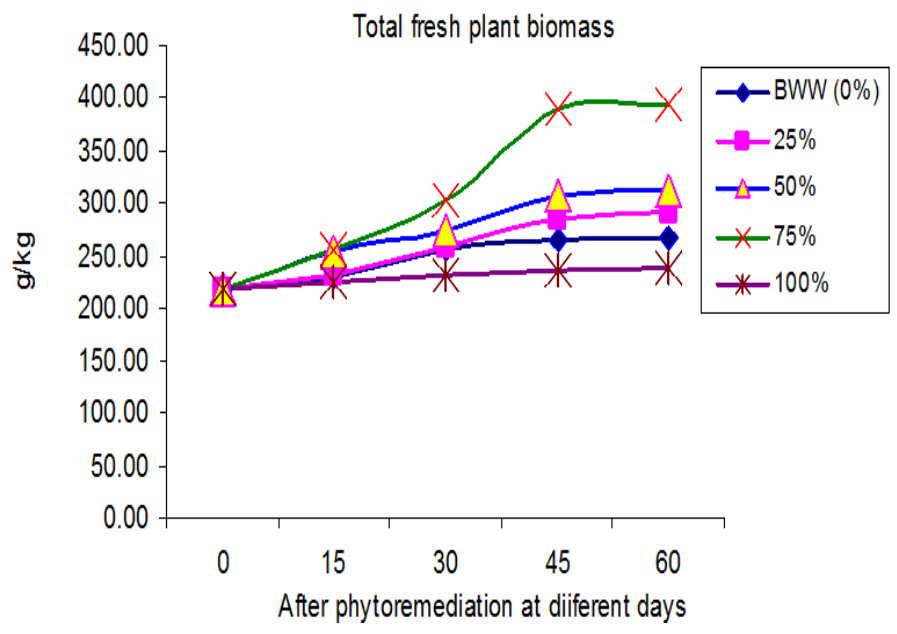

Figure 12. Total fresh plant biomass of E. crassipes after phytoremediation at different days.

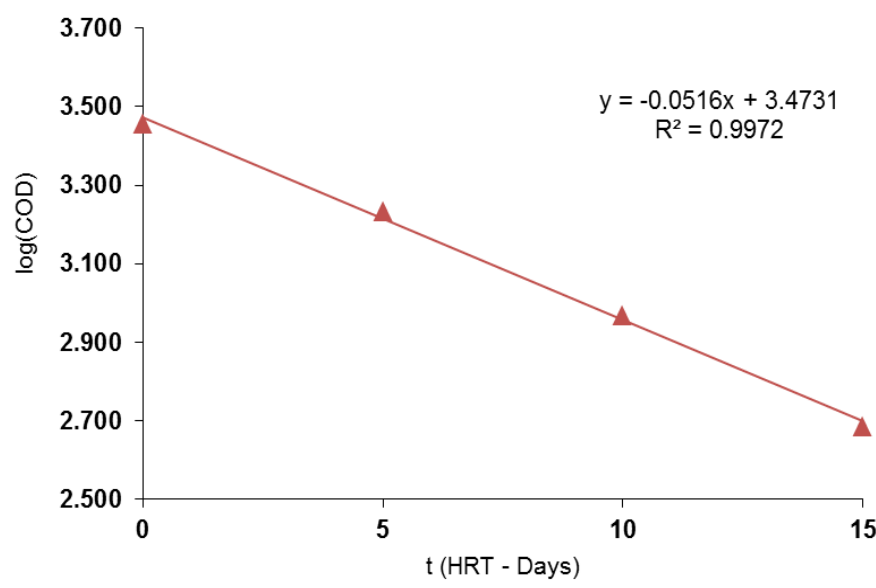

Figure 14. Plot of $\log (C O D)$ vs $t(H R T)$ for kinetic reduction of co-substrate at $40^{\circ} \mathrm{C}$.

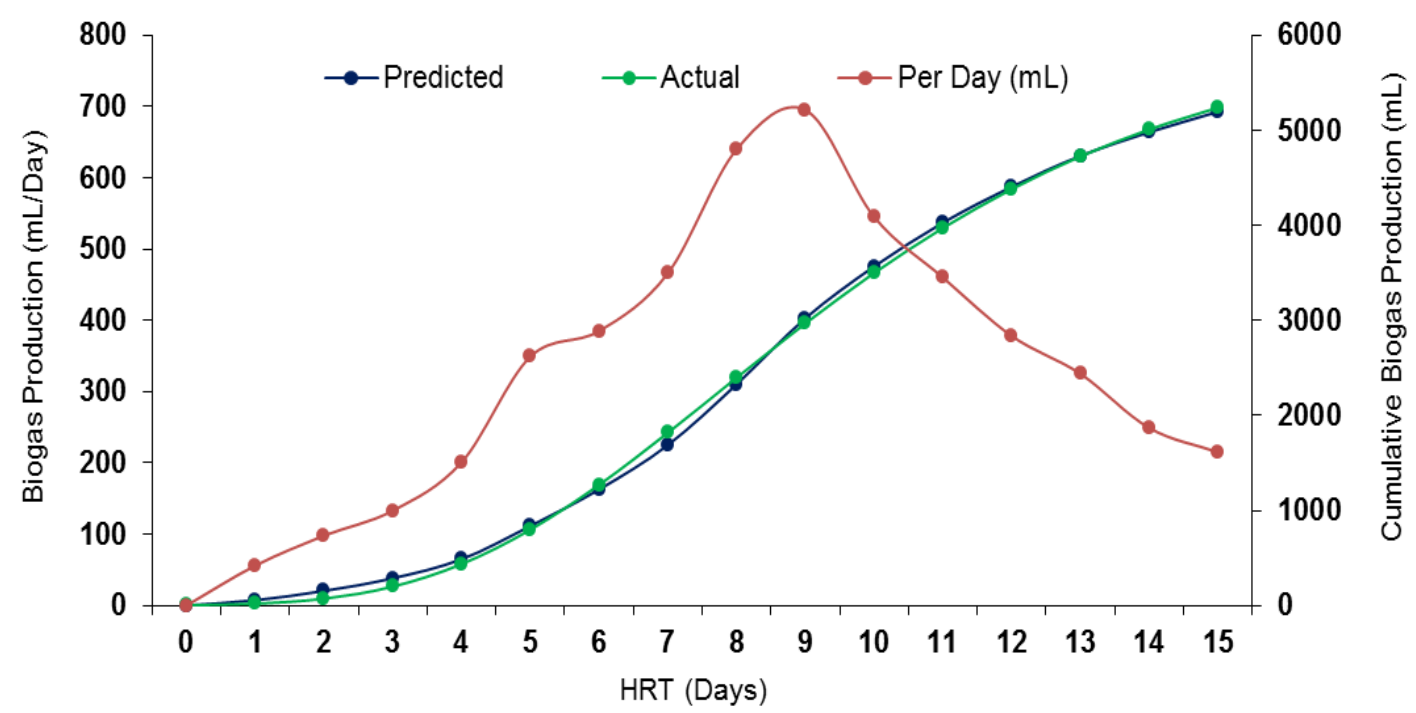

Figure 15. Biogas production (mL/Day) and cumulative biogas production (actual and predicted by modified Gompertz kinetic model). 
Table 5. Changes in parameters of co-substrate used for biogas production at different digestion days.

\begin{tabular}{ccccccccc}
\hline Days & Temperature & $\mathrm{pH}$ & $\mathrm{TS}(\%)$ & $\mathrm{COD}(\mathrm{mg} / \mathrm{l})$ & $\mathrm{VS}(\%)$ & $\mathrm{TOC}(\%)$ & TKN $(\%)$ & $\mathrm{C} / \mathrm{N}$ \\
\hline 0 day & & 7.88 & 64.22 & 2865 & 58.88 & 36.54 & 1.36 & 26.86 \\
$5^{\text {th }}$ day & & $7.07 \mathrm{~ns}$ & $49.54^{* *}$ & $1709^{*}$ & $44.33^{* *}$ & $23.76^{* *}$ & $1.16^{*}$ & $20.48^{*}$ \\
$10^{\text {th }}$ day & $40^{\circ} \mathrm{C}$ & $6.26^{*}$ & $33.21^{* *}$ & $932^{* *}$ & $35.46^{* *}$ & $19.54^{* *}$ & $0.99^{* *}$ & $19.73^{*}$ \\
$15^{\text {th }}$ day & & $6.22^{*}$ & $26.98^{* *}$ & $484^{* *}$ & $27.44^{* *}$ & $13.99^{*}$ & $0.76^{* *}$ & $18.41^{*}$ \\
\hline
\end{tabular}

"Level of significant at $P<0.05$; ${ }^{* *}$ Level of significant at $P<0.01$; ns* Not significant

\section{Conclusion}

The dual approach of this study is to add benefits to phytoremediation of sugar mill effluent by growing water hyacinth and further evaluation of biomass for biogas production. The results of this experiment concluded that E. crassipes significantly reduces both the organic and inorganic pollutants present in the sugar mill effluent. The plant growth attributes of $E$. crassipes viz., fresh weight; total chlorophyll content and kinetic growth rate were found highest in $75 \%$ concentration of the sugar mill effluent during 15-60 days. Beside this, the fresh weights, total chlorophyll content and kinetic growth rate of E. crassipes was decreased when $100 \%$ concentration of sugar mill effluent was used. Additionally, the plant biomass which was grown in the sugar mill effluent was found to have high potential of biogas production. The by-products of the bioreactor residue can be further used as organic fertilizer.

\section{ACKNOWLEDGEMENT}

The University Grants Commission, New Delhi, India is acknowledged to provide Meritorious Rajiv Gandhi National Fellowship (RGNF) F1-17.1/ 2015-16/ RGNF-2015-17-SC-UTT-5597/ (SA-III/ Website) to Jogendra Singh.

Conflict of interest: The authors declare that they have no conflict of interest.

Open Access: This is open access article distributed under the terms of the Creative Commons Attribution License, which permits unrestricted use, distribution, and reproduction in any medium, provided the original author(s) and the source are credited.

\section{REFERENCES}

Akinbile, C.O. and Yusoff, M.S. (2012). Assessing water hyacinth (Eichhornia crassipes) and lettuce (Pistia stratiotes) effectiveness in aquaculture wastewater treatment. International Journal of Phytoremediation, 14(3): 201-211, https:// doi.org/10.1080/15226514.2011.587482

Alade, G.A. and Ojoawo, S.O. (2009). Purification of domestic sewage by water-hyacinth (Eichhornia crassipes). International Journal of Environmental Technology and Management, 10 (3-4): 286-294, https://doi.org/10.1504IJETM.2009.023735

Alam, B. and Chatterjee, A.K. (1994). Ipomea aquatica as a possible biomonitor of aquatic Lead and Chromium Pollution. Recent Researches in Ecology, Environment and Pollution, 9: 217-277.

Annadurai, G., Juang, R.S. and Lee, D.J. (2003). Adsorption of heavy metals from water using banana and orange peels. Water Science and Technology, 47(1): 185-190, https:// doi.org/10.2166/wst.2003.0049

AOAC (2005). In: Official methods of analysis of the association of official analytical chemists. $13^{\text {th }}$ edition, 2005; pp.545-567

APHA (2012). In: Standard methods for the examination of water and waste water. American Public Health and Association (APHA). Washington, D.C. 2012; pp. 2462

Arnon, D.I. (1949). Copper enzymes in isolated chloroplasts. Polyphenoloxidase in Beta vulgaris. Plant physiology, 24(1): 1.

Altaş, L. (2009). Inhibitory effect of heavy metals on methaneproducing anaerobic granular sludge. Journal of Hazardous Materials, 162(2-3): 1551-1556, https://doi.org/10.1016/ j.jhazmat.2008.06.048

Ayyasamy, P.M., Yasodha, R., Rajakumar, S., Lakshmanaperumalsamy, P., Rahman, P.K.S.M. and Lee, S. (2008). Impact of sugar factory effluent on the growth and biochemical characteristics of terrestrial and aquatic plants. Bulletin of Environmental Contamination and Toxicology, 81(5): 449454, https://doi.org/10.1007/s00128-008-9523-5

Baker, A.J.M., McGrath, S.P., Sidoli, C.M.D. and Reeves, R.D. (1994). The possibility of in situ heavy metal decontamination of polluted soils using crops of metal-accumulating plants. Resources, Conservation and Recycling, 11(1-4): 41-49, https://doi.org/10.1016/0921-3449(94)90077-9

Bhadouria, B.S. and Sai, V.S. (2011). Utilization and treatment of dairy effluent through biogas generation a case study. International Journal of Environmental Sciences, 1(7): 1621-1630.

Budiyono, I. and Sumardiono, S. (2014). Kinetic model of biogas yield production from vinasse at various initial $\mathrm{pH}$ : Comparison between modified Gompertz model and first order kinetic model. Research Journal of Applied Sciences, Engineering and Technology, 7(13): 2798-2805.

Chandra, R., Yadav, S. and Yadav, S. (2017). Phytoextraction potential of heavy metals by native wetland plants growing on chlorolignin containing sludge of pulp and paper industry. Ecological Engineering, 98: 134-145, https:// doi.org/10.1016/j.ecoleng.2016.10.017

Chatterjee, A.K. and Nag, U. (1991). Biomonitoring of aquatic metal pollution. International Journal of Occupation and Environmental Health 1(1): 166.

Chaturvedi, R.K. and Sankar, K. (2006). In: Laboratory manual for the physico-chemical analysis of soil, water and plant. Wildlife Institute of India, Dehradun, pp. 97

Dar, S.H., Kumawat, D.M., Singh, N. and Wani, K.A. (2011). Sewage treatment potential of water hyacinth (Eichhornia crassipes). Research Journal of Environmental Science, 5(4): 377-385, http://dx.doi.org/10.3923/rjes.2011.377.385 
Daulta, R., Rani, J. and Yadav, A. (2014). Effect of Sugar Mill Effluent on Physico-chemical Properties of Soil at Panipat City, India, International Archive of Applied Sciences and Technology, 5(2): 06-12.

De, A.K., Sen, A.K., Modak, D.P. and Jana, S. (1985). Studies of toxic effects of $\mathrm{Hg}$ (II) on Pistia stratiotes. Water, Air, and Soil Pollution, 24(4): 351-360, https://doi.org/10.1007/ BF00282487

Dhir, B., Sharmila, P. and Saradhi, P.P. (2009). Potential of aquatic macrophytes for removing contaminants from the environment. Critical Reviews in Environmental Science and Technology, 39(9): 754-781, https://doi.org/ 10.1080/10643380801977776

Dhote, S. and Dixit, S. (2009). Water quality improvement through macrophytes-a review. Environmental Monitoring and Assessment, 152:149-153, https://doi.org/10.1007/ s10661-008-0303-9

Doraisamy, P., Nandakumar, N.B., Maheswari, M. and Selvamurugan, M. (2013). Comparative performance of anaerobic reactors for treatment of sago industry wastewater. Clean Technologies and Environmental Policy, 15 (2); 391-394, https://doi.org/10.1007/s10098-012-0506-1

Dowdy, D.L. and McKone, T.E. (1997). Predicting plant uptake of organic chemicals from soil or air using octanol/water and octanol/air partition ratios and a molecular connectivity index. Environmental Toxicology and Chemistry, 16(12): 24482456, https://doi.org/10.1002/etc.5620161203

Eze, M.O. (2014). Evaluation of heavy metal accumulation in Talinum triangulare grown around municipal solid waste dumpsites in Nigeria. Bulletin of Environment, Pharmacology and Life Sciences, 4: 92-100.

Espinoza-Quinones, F.R., Da Silva, E.A., de Almeida Rizzutto, M., Palácio, S.M., Módenes, A. N., Szymanski, N. and Kroumov, A. D. (2008). Chromium ions phytoaccumulation by three floating aquatic macrophytes from a nutrient medium. World Journal of Microbiology and Biotechnology, 24(12): 3063-3070, https://doi.org/10.1007/s11274-008-9853-9

Goswami, R., Chattopadhyay, P., Shome, A., Banerjee, S.N., Chakraborty, A.K., Mathew, A.K. and Chaudhury, S. (2016). An overview of physico-chemical mechanisms of biogas production by microbial communities: a step towards sustainable waste management. 3 Biotech, 6(1): 72, https:// doi.org/10.1007/s13205-016-0395-9

Hunt, R. (1978). Plant growth analysis. Studies in biology. London: Edward Arnold.1978; P. 67

Hurst (1997). Water Microbiology in Public Health. Manual of Environmental Microbiology. ASM Press, Washington, DC.1997

Jayaweera, M.W., Dilhani, J.A., Kularatne, R.K. and Wijeyekoon, S.L. (2007). Biogas production from water hyacinth (Eichhornia crassipes (Mart.) Solms) grown under different nitrogen concentrations. Journal of Environmental Science and Health Part A, 42(7): 925-932, https:// doi.org/10.1080/10934520701369842
Juárez-Santillán, L.F., Lucho-Constantino, C.A., VázquezRodríguez, G.A., Cerón-Ubilla, N.M. and Beltrán-Hernández, R.I. (2010). Manganese accumulation in plants of the mining zone of Hidalgo, Mexico. Bioresource Technology, 101(15): $\quad$ 5836-5841, https://doi.org/10.1016/j. biortech.2010.03.020

Kim, K.H. and Kim, S.H. (1999). Heavy metal pollution of agricultural soils in central regions of Korea. Water, Air, and Soil Pollution, 111(1-4): 109-122, https://doi.org/10.1023/ A:1005056310428

Kumar, V. and Chopra, A.K. (2016). Reduction of pollution load of paper mill effluent by phytoremediation technique using water caltrop (Trapa natans L.). Cogent Environmental Science 2:1153216, https// doi.org/10.1080/23311843.2016.1153216

Kumar, V. and Chopra, A.K. (2017). Phytoremediation potential of water caltrop (Trapa natans L.) using municipal wastewater of activated sludge process based municipal wastewater treatment plant. Environmental Technology, https://doi.org/10.1080/09593330.2017.1293165

Kumar, V., Chopra, A.K., Singh, J., Thakur, R.K., Srivastava, S. and Chauhan, R.K. (2016). Comparative assessment of phytoremediation feasibility of water caltrop (Trapa natans L.) and water hyacinth (Eichhornia crassipes Solms.) using pulp and paper mill effluent. Archives of Agriculture and Environmental Science, 1(1): 13-21.

Kumar, V., Singh, J. and Chopra, A. K. (2017). Assessment of phytokinetic removal of pollutants of paper mill effluent using water hyacinth (Eichhornia crassipes [Mart.] Solms). Environmental Technology, 1-11, https://doi.org/10.1080/09593330.2017.1365944

Kumar, V., Singh, J., Pathak, V.V., Ahmad, S. and Kothari, R. (2017). Experimental and kinetics study for phytoremediation of sugar mill effluent using water lettuce (Pistia stratiotes L.) and its end use for biogas production. 3 Biotech, 7(5):330, https://doi.org/10.1007/s13205-017-0963-7

Kumar, V., Singh, J., Nadeem, M., Kumar, P. and Pathak, V.V. (2018). Experimental and kinetics studies for biogas production using water hyacinth (Eichhornia crassipes [Mart.] Solms) and sugar mill effluent. Waste and Biomass Valorization, 1-11, https://doi.org/10.1007/s12649-018-0412-9

Li, M., Zhao, Y., Guo, Q., Qian, X. and Niu, D. (2008). Bio-hydrogen production from food waste and sewage sludge in the presence of aged refuse excavated from refuse landfill. Renewable Energy, 33(12): 2573-2579, https://doi.org/10.1016/j.renene.2008.02.018

Lin, C.Y. and Shei, S.H. (2008). Heavy metal effects on fermentative hydrogen production using natural mixed microflora. International Journal of Hydrogen Energy, 33(2): 587-593, https://doi.org/10.1016/j.ijhydene.2007.09.030

Manjula, D.G. and Mahanta, P. (2014). Comparison of kinetic models for biogas production rate from saw dust. International Journal of Research in Engineering and Technology, 3(7): 248-254. 
Mathew, A.K., Bhui, I., Banerjee, S.N., Goswami, R., Chakraborty, A.K., Shome, A. and Chaudhury, S. (2015). Biogas production from locally available aquatic weeds of Santiniketan through anaerobic digestion. Clean Technologies and Environmental Policy, 17(6): 1681-1688, https:// doi.org/10.1007/s10098-014-0877-6

Mazumdar, K. and Das, S. (2015). Phytoremediation of Pb, Zn, $\mathrm{Fe}$, and $\mathrm{Mg}$ with 25 wetland plant species from a paper mill contaminated site in North East India. Environmental Science and Pollution Research, 22(1): 701-710, https:// doi.org/10.1007/s11356-014-3377-7

Mellem, J.J., Baijnath, H. and Odhav, B. (2009). Translocation and accumulation of $\mathrm{Cr}, \mathrm{Hg}, \mathrm{As}, \mathrm{Pb}, \mathrm{Cu}$ and $\mathrm{Ni}$ by Amaranthus dubius (Amaranthaceae) from contaminated sites. Journal of Environmental Science and Health Part A, 44(6): 568-575, https://doi.org/ 10.1080/10934520902784583

Mellem, J.J., Baijnath, H. and Odhav, B. (2012). Bioaccumulation of $\mathrm{Cr}, \mathrm{Hg}, \mathrm{As}, \mathrm{Pb}, \mathrm{Cu}$ and $\mathrm{Ni}$ with the ability for hyperaccumulation by Amaranthus dubius. African Journal of Agricultural Research, 7(4): 591-596, https://doi.org/10.5897/ AJAR11.1486

Mishra, S. and Maiti, A. (2017). The efficiency of Eichhornia crassipes in the removal of organic and inorganic pollutants from wastewater: a review. Environmental Science and Pollution Research, 24(9): 7921-7937, https:// doi.org/10.1007/s11356-016-8357-7

Mukherjee, S. and Kumar, S. (2005). Arsenic uptake potential of water lettuce (Pistia Stratiotes L.). International Journal of Environmental Studies, 62(2): 249-258, https:// doi.org/10.1080/00207230500037068

Newete, S.W. and Byrne, M.J. (2016). The capacity of aquatic macrophytes for phytoremediation and their disposal with specific reference to water hyacinth. Environmental Science and Pollution Research, 23(11): https://doi.org/10.1007/ s11356-016-6329-6

O'Sullivan, C., Rounsefell, B., Grinham, A., Clarke, W. and Udy, J. (2010). Anaerobic digestion of harvested aquatic weeds: water hyacinth (Eichhornia crassipes), cabomba (Cabomba Caroliniana) and salvinia (Salvinia molesta). Ecological Engineering, 36(10): 1459-1468, https://doi.org/10.1016/ j.ecoleng.2010.06.027

Samuel, J., Kumar, S.G.L. and Rintu, B. (2017). Kinetic modeling of mixed culture process of anaerobic co-digestion of vegetable wastes with Pistia stratiotes: A scientific attempt on biomethanation. Journal of Microbiology, Biochemistry and
Technology 9: 036-048, https://doi.org/10.4172/19485948.1000341

Sawant, A.A., Hegde, N.V., Straley, B.A., Donaldson, S.C., Love, B.C., Knabel, S.J. and Jayarao, B.M. (2007). Antimicrobialresistant enteric bacteria from dairy cattle. Applied and Environmental Microbiology, 73(1): 156-163, https:// doi.org/10.1128/AEM.01551-06

Sen, A.K. and Bhattacharyya, M. (1993). Studies on uptake and toxic effects of lead on Salvinia natans. Indian Journal of Environmental Health, 35(4): 308-320.

Sharma, G., Zaidi, J. and Pal, A. (2014). Remediation of heavy metals through aquatic macrophytes from water bodies of Bundelkhand region of Uttar Pradesh. Journal of Ecophysiology and Occupational Health, 14(3-4): 189-196, https:// doi.org/10.18311/jeoh/2014/1663

Sooknah, R.D. and Wilkie, A.C. (2004). Nutrient removal by floating aquatic macrophytes cultured in anaerobically digested flushed dairy manure wastewater. Ecological Engineering, 22(1): 27-42, https://doi.org/10.1016/ j.ecoleng.2004.01.004

Srivastava, S., Singh, B., Yadav, A., Singh, P.K., Srivastava, V. and Shukla, D.N. (2014). Bioaccumulation and translocation efficiency of heavy metals in Eichhornia crassipes (C. Mart.) Solms. grown on sulem sarai wetland, Allahabad, Uttar Pradesh, India. Asian Journal of Biochemical and Pharmaceutical Research, 3(4): 263-269.

Victor, K.K., Séka, Y., Norbert, K.K., Sanogo, T.A. and Celestin, A.B. (2016). Phytoremediation of wastewater toxicity using water hyacinth (Eichhornia crassipes) and water lettuce (Pistia stratiotes). International Journal of Phytoremediation, 18(10):949955,https://doi.org/ 10.1080/15226514.2016. 1183567

Wang, X., Lu, X., Li, F. and Yang, G. (2014). Effects of temperature and carbon-nitrogen $(\mathrm{C} / \mathrm{N})$ ratio on the performance of anaerobic co-digestion of dairy manure, chicken manure and rice straw: focusing on ammonia inhibition. PloS One, 9(5):97265, https://doi.org/10.1371/journal.pone.0097265

Wilkie, A.C., Riedesel, K.J. and Owens, J.M. (2000). Stillage characterization and anaerobic treatment of ethanol stillage from conventional and cellulosic feedstocks. Biomass and Bioenergy, 19(2): 63-102, https://doi.org/10.1016/S09619534(00)00017-9

Yoon, J., Cao, X., Zhou, Q. and Ma, L.Q. (2006). Accumulation of $\mathrm{Pb}, \mathrm{Cu}$, and $\mathrm{Zn}$ in native plants growing on a contaminated Florida site. Science of the Total Environment, 368(2-3): 456-464, https://doi.org/10.1016/j.scitotenv.2006.01.016 